\title{
The weathering of stone-built heritage: a lens through which to read the
}

\section{Anthropocene}

\author{
M. Gomez-Heras \& S. McCabe
}

\begin{abstract}
This paper presents a discussion showing how the study of stone-built heritage decay is relevant in the context of the Anthropocene by raising the complex two-way interplay between stone and society. Stone heritage, natural and built, is an asset that is vulnerable to present and future climate change but, especially in the context of built heritage, stone can also be conceptualized as a "large scale laboratory" in which the evolution of weathering, and thus past exposure conditions, can be studied (analogous to physical landscape studies). This concept of built heritage as a 'recorder' of past environmental evolution is found from the very first moments of the development of earth sciences as a formal discipline. The ideas reviewed and presented in the paper show how stone surfaces may be used to "read" background environmental changes, pollution changing trends and even catastrophic events, such as fire, teaching us both about the past (since human interactions with stone began, and as these intensified through history) and about the nature of weathering. The understanding of how these past environmental changes left a trace in stone allow us to use them as a means of understanding the potential impacts of future change. Such an understanding may be used both to inform conservation management of, and also plan for future climate impacts on, our irreplaceable stone-built heritage assets.
\end{abstract}

Key words: Anthropocene, stone decay, environmental change, weathering 


\section{Introduction: the Anthropocene as a time of mutual impact between humans and}

\section{the Earth system}

The Anthropocene, a term coined by Crutzen and Stoermer (2000), has become a widely used concept to denote the stage in which the impact of human beings on the earth system has increased to the extent that consequent changes in the system are observable. Despite the contention on the stratigraphical value of the term 'Anthropocene' as formal unit (Finney, 2014; Waters et al., 2014) and the debate on the starting point of this epoch in terms of 'geological time' (Ruddiman et al., 2015), the birth of this term and its widespread use mark a milestone of the awareness of humanity of its own impact on the earth and atmospheric system.

The use of the term Anthropocene is not the first attempt at defining the influence of humankind on the earth system in terms of a time period. In the 19th century, Stoppani used the term "anthropozoic era" (Goudie, 2000, pp. 4-5) to label the impact of humans on the Earth. Nevertheless, none of the previous attempts to label this influence have achieved the widespread use and acceptance that 'Anthropocene' is presently enjoying. Ruddiman et al., (2015) have thus suggested that "the term 'Anthropocene' is clearly here to stay".

While the focus of the Anthropocene has been on the impact of human activity on the earth system, it is worth considering the Anthropocene as a time of mutual impacts between humans and the Earth system, where each influences the behavior of the other in a complex two-way interaction. As Smith and Zeder (2013) pointed out, the term Anthropocene raised a question regarding when humans began to exert a detectable influence on the earth's environments but, in the opinion of the authors, one 
could think of the Anthropocene as the time in the history of humankind in which the mutual impacts between civilisation and earth system have become apparent.

As well as human impact on earth systems by, for example, quarrying or building, changing earth systems impact on society (for example, climate change and the influence of environmental dynamics on our buildings and infrastructure systems) leaving physical traces that can be read as a witness of those changing dynamics. One example where these mutual impacts between the earth system and humankind can be studied is in stone-built heritage and its associated activities. Stone heritage is ubiquitous across the globe - from ancient megaliths, to medieval ecclesiastical structures, to modern day 'high prestige' buildings. This paper cannot examine human/stone heritage interactions exhaustively, but will seek to give examples of key ways in which society impacts on rock weathering. The decay of stone heritage is a particular case of rock weathering in which the 'stakes are raised' because the immaterial values (experiential, spiritual, aesthetic) added to a particular building or structure are juxtaposed with the natural inevitable process of weathering observed in any exposed environment.

Whether or not we can classify the Anthropocene as a geological epoch has been debated (see discussion outlined by Oldfield et al. 2014), but is not a major concern of this paper. Rather, it is our purpose to outline how human activity has impacted on stone - broadly in the natural environment, but particularly drawing lessons from the built heritage (which is, of course, one of the great examples of human interaction with stone over the course of civilisation) and to discuss how building stone has the potential to be a 'recorder' of such activity, and therefore a resource to read change in Anthropocene. 


\section{Stone as a part of physical and cultural landscapes}

Stone and stone-built heritage are an essential ingredient in the aesthetics of landscape, and the behaviour of stone is a crucial part of landscape evolution and development. Much of the world's tangible cultural heritage is built of stone and stone use in heritage and its conservation has been subject of extensive research for over a century, as shown in monographic texts on the subject (Schaffer, 1932; Winkler, 1973; Price, 1996; Doehne and Price, 2010).

Although often studied separately, it is necessary to realize the concepts of natural and cultural heritage are closely related (not least because stone is often a spectacular and enduring aspect of both), and in fact often have overlapping, or directly integrated, legislation. Moreover, the built heritage often uses local materials which are related to the geology of the immediate surroundings so that the built heritage often reflects 'the terroir', blending geology, geomorphology and built heritage (Garcia-Rodriguez et al., 2015) to give a unique sense of place. As a result of these interrelationships, in 1972 UNESCO established the importance of their joint protection at the Convention on the Protection of the World Cultural and Natural Heritage. This convention encouraged the adoption of joint policies with the aim of recognising the role of cultural and natural heritage in the life of communities. As an example of this, there are 24 places in the world with the joint inscription of natural and cultural heritage, as World Heritage and Geoparks initiatives underline the importance of a holistic understanding of the natural and cultural heritage in terms of the decisive influence of geology, geomorphology and the landscape on society, civilization and cultural diversity (Carcavilla Urquí, 2012).

Societal interaction with stone landscapes has, of course, been extensive. People have been building in stone for thousands of years and perhaps quarrying is one of the 
hallmarks of the Anthropocene. The stone quarrying industry has been, and remains, a key element in flourishing economies - not only for building materials, but also for acquiring mineral resources as "stuff for things" (Simmons 1974, 264). Yet there are negative implications too in the exploitation of stone landscapes, in terms of quarries being seen as dusty, noisy industrials sites that leave deep 'scars' in natural landscapes, displacing wildlife and irrevocably altering aesthetics. They are also a potential hazard risk to the public in regard to contaminated water and dangerous drops. Added environmental impacts of quarrying are the ancillary activities and pollution related to transportation networks, especially of rail and road (through the industrial revolution and into the present day). Of course, such impacts are increasingly partially 'off-set' through the management of disused quarries for biodiversity and recreation. As such, disused quarries represent an opportunity to manage land for ecosystem services (Bloodworth et al. 2009).

Identifying and understanding the complex histories of physical and cultural landscapes is the goal of numerous disciplines, and much can be learned from the cross-pollination of ideas and approaches. The understanding of how landscapes have formed and developed over time has, for example, been a traditional goal of geomorphological studies (Smith et al. 1999, Jones 1999). Though not explicitly discussed in geomorphological literature (to these authors' knowledge), geomorphologists and other related earth scientists develop, over time, an eye for 'reading' landscapes, whereby the histories of landscapes can be determined or inferred by the features, or physical forms, in evidence (Thornes and Brunsden 1977). Geomorphologists have inherited an important 'Anthropocene' perspective, namely that "landscapes are not 'clean' pure products of contemporary processes but have in 
them a background of residual effects of earlier periods" (Thornes and Brunsden 1977, 19), including interactions with society.

There are also landscape archaeologists and historians who refer to 'reading the landscape', where the legacy of past cultures and communities have impacted on the countryside (Muir 2001). Just as with "palimpsests", (old manuscripts that have been reused after scraping away the old text which is often left partially visible) landscapes may be seen as a collection of layered 'memories' (both in the physical system, but also cultural) relating to events that have shaped the land.

\section{Stone-built heritage: 'asset' and 'recorder'}

Considered in a broad sense, Cultural and Natural Heritage, 'Heritage' can be defined as the group of goods, resources, spaces and places, to be protected and preserved for posterity. It is both what society inherits, and also what it hopes to pass on to future generations. The concept of heritage is based on an appreciation of the value of a given asset and it is, therefore, a concept that does not depend on the specific object but is based on the values that society generally attributes to a specific asset at a determined historic, cultural and scientific moment. It is therefore a subjective and changing concept. The concept of heritage entangles a sense of uniqueness, value and the need to protect an object - all of these things adding intangible, but very important, aspects of value. The perception of societies on what is valuable or not becomes a factor to be considered in relation to the mutual influence between Earth systems and humankind, as these influences will be considered in a different way depending on whether or not they are seen to affect something considered valuable.

Since stone-built heritage (or, in a broader sense, "cultural stone" in the definition of Pope et al. (2002), i.e. stone that has been physically altered by humans) is considered 
valuable in many different ways (an asset reflecting its own unique story, an artefact which becomes a compilation of its own history, a resource for society to exploit through, for example, tourism), its decay due to environmental factors, although an inevitable consequence of natural weathering, is seen as something undesirable. Throughout the entire record of history there have been references to the deterioration of stone-built monuments, and also measures for the protection of the architectural and artistic heritage. The Natural History of Pliny the Elder, for example, includes many observations on monuments, referring to their condition and lamenting the lack of protective measures.

There are some early references regarding experimental tests on stone buildings from the early nineteenth century as in the case of De Thury (1828) who conducted a review on the use of salt crystallization tests as an analogue to frost action in building stone. However, the study of the deterioration of stone in a built context began to really develop as a discipline in its own right during the second half of the nineteenth century and early twentieth century. This is mainly due to two reasons: towards the second half of the nineteenth century the first public institutions and legal standards for the protection of assets consolidated (Poblador Muga, 2001) and also during that century an interest developed in improving the selection of appropriate stone materials for new works. This period saw the entry of new types of building stone corresponding with transportation improvements (Gomez-Heras and Fort 2004; Gomez-Heras et al. 2010). Thus architects began to shift from a qualitative understanding of the behaviour of traditional materials (Schaffer 1932) to see the value of selecting materials from a wider and more quantitative point of view. These growing concerns opened the way for the experimental development of the discipline of study the deterioration of stone materials in architecture. The discipline of studying 
the deterioration of stone materials applied to construction was already developing in the first half of the twentieth century, with the first monographic texts on stone building and deterioration as Howe's (1910) or Schaffer's (1932), one of the first specific texts on the weathering of stone in buildings. The study of stone-built heritage decay has, since then, become a multidisciplinary field, benefitting from a variety of approaches and knowledge bases.

One of the reasons this discipline developed was the increasing rate of deterioration inflicted on the stone heritage during the $19^{\text {th }}$ Century, after the industrial revolution. Brimblecombe and Camuffo (2002) noted that, during Victorian times, choosing building stone types that could resist enhanced pollution was already a concern. Interest in understanding and managing decay has thus reflected a period in which decay due to human influence has increased. During the $19^{\text {th }}$ and specially the $20^{\text {th }}$ century the rate of stone decay increased dramatically when compared to the rate of deterioration in previous centuries, which highlights the 'anthopocenic' character of stone decay processes, especially due to increased air pollution levels that greatly affect stone (Winkler 1973; Amoroso and Fassina 1983; Brimblecombe 1987; Mingarro 1996; Price 1996).

Decay processes occurring on a building do not differ substantially from rock weathering in natural environments - albeit, the stress history can be more anthropogenic in nature, with the whole entourage of human-controlled weathering agents acting in the built environment (perhaps superimposed on natural processes). This similitude of processes has been long recognized by Earth scientists and, as early as 1880, Archibald Geikie wrote: "nowhere can the nature of weathering be more conveniently and instructively studied than upon ancient masonry" (Geikie 1887, p. 15). Because of this, manifestations of weathering and decay in stone-built heritage 
can be considered, using the same terminology mentioned above for landscapes, as a palimpsest of traces left by environmental changes that can be read to understand environmental evolution. Stone heritage, then, because it reflects its own history, can be seen as a 'recorder' of change.

There is already a tradition of using the term 'Anthropocene' when considering archaeological evidence as a tool to learn from environmental changes in the past and their interaction with humans (Erlandson and Braje, 2013; Kennett and Beach, 2013; Rick et al., 2013). However, although stone decay studies have a deep Anthropocenic connotation, this term has not been used before, to the authors' knowledge, in the context of stone decay studies.

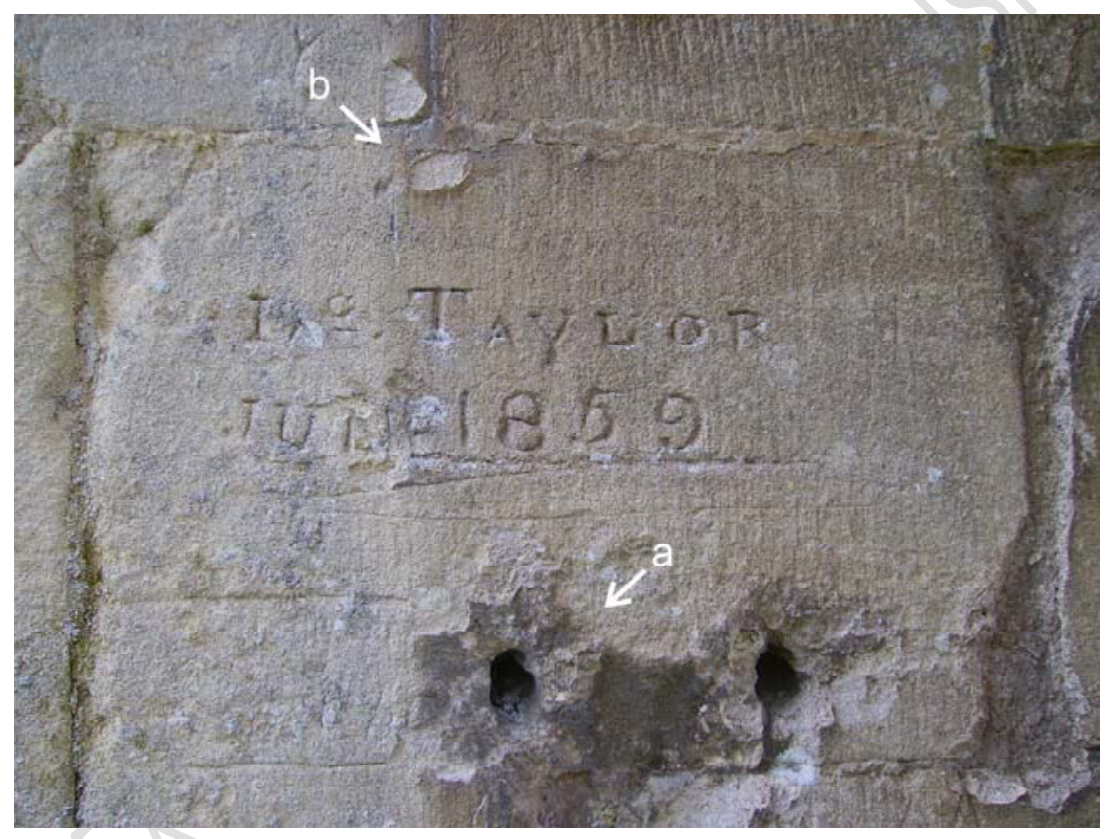

Figure 1: Graffiti at Hailes Abbey (England) allows a temporal measure between the detachment of a hardened surface prior to 1859 (a) and the recent initiation of a new detachment associated with mortar repointing (b).

Nevertheless, stone-built heritage exposed to the environment is a major scientific resource in terms of understanding environment change. The date of exposure of most 
stone-built structures is known, and when these structures have a marked heritage status, they are likely to have historical images and descriptions, becoming of significant value to those studying environmental change over time (Figure 1). A good example of the use of stone-built structures as a scientific resource in Earth Sciences is found in utilisation of tombstones in the calibration of lichenometric dating (Beschel 1950). Tombstones and other monuments have been also used by researchers to assess weathering rates (e.g. Goodchild 1890, Matthias 1967, Klein 1984). Relationships between modelled $\mathrm{SO}_{2}$ concentrations during the $20^{\text {th }}$ century and decay rates of marble tombstones have been also established (Meierding 1993), supporting the case for accelerated decay processes of building stone during the Anthropocene.

This idea of using stone-built heritage decay as a proxy for environmental change is not a new thing. In fact, it dates back to the articulation of Geology as a science. Lyell (1830) stated, referring to Figure 2, "This celebrated monument of antiquity, affords in itself alone, unequivocal evidence that the relative level of land and sea has changed twice at Puzzuoli since the Christian era; and each movement, both of elevation and subsidence, has exceeded twenty feet." (Principles of Geology, Chapter XXIX, p. 449). 


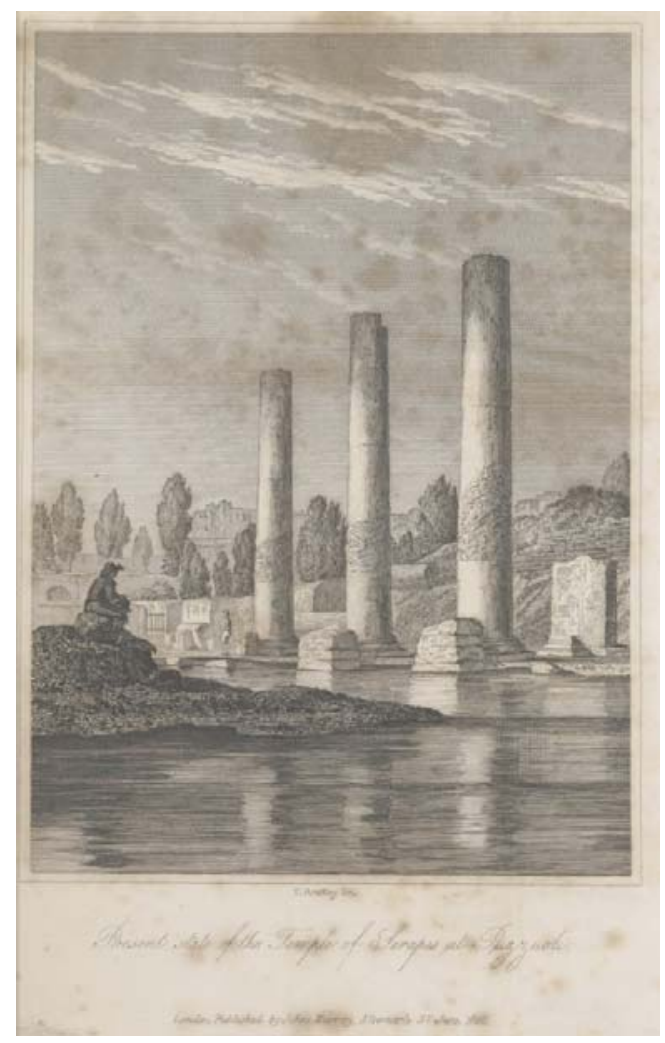

Figure 2: Frontispiece of Charles Lyell's (1830) Principles of Geology (Reproduced with permission from John van Wyhe ed. 2002. The Complete Work of Charles Darwin Online: http://darwinonline.org.uk/)

This fine example given by Lyell of reading environmental change in stone acquires a new meaning under the light of recent and projected environmental change as "the impacts of Climate Change are affecting many and are likely to affect many more World Heritage properties, both natural and cultural in the years to come" (World Heritage Committee, 2005). From the point of view of the research community, Viles (2002) explored how climate change may impact on stone decay. Several works within the 6th EU framework program 'Noah's Ark: Global Climate Change Impact on Built Heritage and Cultural Landscapes' echoed the concern expressed, recognizing the effect that climate change has on the architectural heritage (Sabbioni et al., 2006; Bonazza et al, 2009a;. Gómez-Bolea et al, 2012) and also, therefore, a 
potential evidence base for understanding and verifying climate change impacts. These studies recognize that climate change will continue throughout the 21 st century and has the potential of impacting on stone built heritage and the weathering processes and mechanisms acting on it (Brimblecombe and Grossi, 2007; Smith et al, 2011a; 2011b; McCabe et al, 2013b). In line with this knowledge the UNESCO continues publishing documents such as "Case studies on Climate Change and World Heritage" (Colette 2007) and "Climate change adaptation for natural World Heritage sites: a practical guide" (Perry and Falzon 2014).

Furthermore, stone decay patterns are not only sensitive to extreme events or largescale trends in climate change. Divergent weathering evolution may be found in even relatively short time periods due to subtle variations in micro-environmental conditions. For example, small scale thermal fluctuations, both spatially (Hall and André, 2003; Gomez-Heras et al, 2006a) and temporally (Jenkins and Smith 1990, Halsey et al., 1998) have been found to be of paramount importance in considering thermal weathering, albeit, it has been considered a relatively inefficient weathering agent when considered in isolation. For example, Gomez-Heras et al. (2008a) reported how the multiplication of short-term, small-scale, heating-cooling cycles caused by trees projecting shadows on the façades of a mid $20^{\text {th }}$ century building in middle latitudes could trigger thermal weathering. Similarly, small changes in relative humidity may also lead to an increased frequency of, for example, salt crystallization cycles and a consequent acceleration of weathering rates in building stone (Benavente et al., 2008) as it does in natural environments (Mol 2014). These previous examples illustrate how the change in microenvironment is subtly 'recorded' by a corresponding change in the stone (for example the appearance of a certain decay pattern) due to a change in the weathering processes acting. They also lead to the idea 
that stone-built heritage may be seen as a large-scale laboratory to understand how weathering processes and, more widely, how Anthropocene activity, may be recorded in stone over time.

\section{Stone in buildings - Smith's 'Great Weathering Experiment'}

A stone building or monument façade can be viewed as a kind of 'landscape' (albeit on a different plane and scale). In the same way that a 'natural landscape' is made up of small-scale debris and soils mantling a variety of landforms which together form the larger landscape, buildings comprise individual small-scale elements such as stone blocks and carved details, placed within individual façades which taken together form the larger structure.

A key question, therefore, is whether it is possible to 'read' a stone building or monument in the same way that a landscape might be read, by seeing subtle clues as to what has gone before - are signs of anthropogenic impact embedded in the 'memory' of stone? One obvious difficulty in 'reading' stone in a building is that manifestations of previous events may no longer, or may not yet, be overtly visible on the stonework. McCabe et al. (2007b) highlight, for example, the different possibilities of 'memory' that are likely to exist across a façade - past events causing stress within the stone may already have been exploited, may currently be being exploited, or may have yet to be exploited.

Seeing how stone performs in buildings, where weathering processes can be intensified by human influences, causing accelerated breakdown, can teach us about the behaviour of stone in natural landscapes over time in response to natural and anthropogenic factors, and about those influencing factors themselves. This is what geomorphologist Bernard Smith termed 'the Great Weathering Experiment' (Smith 
2005). We may reasonably view cities as a stone weathering laboratory, where stone change can be monitored more easily than in natural and traditionally studied weathering environments (for example, arid and tropical climates). Stone used in buildings, in accumulating stresses over their exposure history, can be conceptualised as an especially sensitive environmental 'recorder' (when compared to stone in the natural landscape) - reflecting the impact of environmental change and human activities (for example, pollution) over time. Its utility as an environmental recorder, however, can be masked by the complex nature of the stone/environment interface (and the changing sensitivity of the surface in response to, for example, soiling) (McCabe et al. 2015).

As suggested above, there is an argument to be made that stone in structures may be investigated in a similar way to stone in landscapes. Woodcock $(1997,37)$ writes about the value of "reading buildings instead of books... a challenge involving physical and historical investigation through field work and documentary research, followed by analytical consideration of the findings and by an assessment of the probable causes of observed problems". He proposes that a major purpose in 'reading' a building is appreciating the stresses to which materials are subjected over time. From an earth sciences, and particularly geomorphological perspective (described above), this should not just be an assessment of contemporary stresses, but of complex stress histories, where stones "have in them a background of residual effects of earlier periods" (Thornes and Brunsden 1977, p. 19). This has also been called stone 'inheritance' (Warke 1996) or 'the memory effect' (Cooke 1989). Examples have been detailed in stresses, sometimes directly caused by humans, experienced by medieval ecclesiastical stone structures in the northwest of the British Isles (see McCabe et al. 2010a), which commonly experience a long and varied history, often 
through times of conflict (also see McCabe and Smith 2009). Further examples are set out in Table 1.

Along with the possibility of stone 'losing' the 'memory' of a past event that brought about stress (through, for example, surface material loss), a limiting factor in 'reading' a building, and in linking decay with the processes or Anthropocenic events that brought it about is the concept of 'equifinality'. Equifinality essentially describes the difficulty of identifying all different possible stress histories produced by different possible processes and mechanisms over time, on the basis of investigating contemporary stone decay forms in evidence (Beven, 1996) - it literally means 'equal finish', i.e. different process can lead to the same end product in terms of decay form. In essence, different process combinations in different sequences acting on stone mean that, in the real world, 'reading' a façade with respect to linking form and process is a difficult undertaking - essentially, an expert system. Some opportunities and obstacles to this are discussed with below.

\section{Reading the Anthropocene in stone}

Before 'reading' past events on a façade, it is essential that background research is carried out into the history of the subject building (past stress events and the environment to which it has been exposed), the materials and techniques used in quarrying and construction, and possible conservation intervention that has been undertaken in the past (see, for example, McCabe et al. 2010a). Following this collation of background knowledge, the first step in 'reading' a façade is to understand the underlying nature of the weathering or decay. Decay can be either chronic (associated with long-term decline) or acute (Smith and Prrikryl, 2007) (potentially the result of, for example, extreme frost events, over-energetic cleaning, 
and inappropriate interventions, but especially associated with catastrophic events such as fire). Table 1 summarises common decay features associated with the chronic decay of historic stone, their key controls, and their potential role in long-term weathering.

Table 1. Common features associated with chronic decay, their key controls and potential role in the long-term behaviour of stone.

\begin{tabular}{|c|c|c|}
\hline Feature & Key controls & $\begin{array}{l}\text { Potential role in long-term } \\
\text { behaviour of stone }\end{array}$ \\
\hline Salt accumulation & $\begin{array}{l}\text { - Proximity to source (marine, } \\
\text { pollution) } \\
\text { - Temperature and moisture } \\
\text { fluctuations } \\
\text { - Porosity / permeability } \\
\text { characteristics of stone }\end{array}$ & $\begin{array}{l}\text { - Material loss } \\
\text { - Surface efflorescence / sub- } \\
\text { efflorescence } \\
\text { - Surface pitting } \\
\text { - Synergy with chemical alteration } \\
\text { - mobilisation of, for example, } \\
\text { silica and iron }\end{array}$ \\
\hline Greening & $\begin{array}{l}\text { - Ability of surface to sustain life } \\
\text { - Moisture availability } \\
\text { - Shelter of other vegetation } \\
\text { - Pollution (presence of NOx may } \\
\text { encourage colonisation) }\end{array}$ & $\begin{array}{l}\text { - Retention of moisture } \\
\text { - 'Sealing' of the surface } \\
\text { - Synergy with salt accumulation } \\
\text { and retention }\end{array}$ \\
\hline $\begin{array}{l}\text { Alveolar } \\
\text { weathering }\end{array}$ & $\begin{array}{l}\text { - Salt accumulation } \\
\text { - Chemical alteration (iron migration } \\
\text { from substrate to surface) } \\
\text { - Aspect / prevailing wind direction }\end{array}$ & $\begin{array}{l}\text { - Material loss, developing } \\
\text { caverns in surface } \\
\text { - Weakening of substrate (loss of } \\
\text { cement) }\end{array}$ \\
\hline Lichen growth & $\begin{array}{l}\text { - Environmental regime } \\
\text { - Ability of surface to sustain life } \\
\text { - Stone surface micro-topography and } \\
\text { porosity / permeability control } \\
\text { infiltration of hyphae }\end{array}$ & $\begin{array}{l}\text { - Material loss upon shrinkage of } \\
\text { lichen (especially effective on } \\
\text { sandstones with high porosity) } \\
\text { - Secretion of organic acids, } \\
\text { chemical alteration } \\
\text { - Synergy with salt accumulation }\end{array}$ \\
\hline Chemical alteration & $\begin{array}{l}\text { - Stone mineralogy (especially iron } \\
\text { content) } \\
\text { - Salinity and pH of moisture ingress } \\
\text { - Environmental regime }\end{array}$ & $\begin{array}{l}\text { - Dissolution, migration and re- } \\
\text { precipitation of iron } \\
\text { - Surface hardening / subsurface } \\
\text { weakening } \\
\text { - Material loss in solution } \\
\text { - Loss of cement / weakening of } \\
\text { grain boundaries } \\
\text { - Synergy with salt accumulation }\end{array}$ \\
\hline $\begin{array}{l}\text { Preferential } \\
\text { weathering of } \\
\text { bedding planes }\end{array}$ & $\begin{array}{l}\text { - Structure of stone (obvious presence } \\
\text { of bedding), exploitation of lines of } \\
\text { weakness } \\
\text { - Supply of salts and moisture } \\
\text { - Nature of temperature fluctuations }\end{array}$ & - Material loss \\
\hline
\end{tabular}




\begin{tabular}{lll}
\hline $\begin{array}{l}\text { Material } \\
\text { detachment }\end{array}$ & $\begin{array}{l}\text { Weathering environment - this is a } \\
\text { manifestation of decay processes }\end{array}$ & $\begin{array}{l}\text { Surface retreat can result in the } \\
\text { disappearance of whole blocks in } \\
\text { the long-term }\end{array}$ \\
- Supply of salts & Accumulation of salts in the \\
substrate ('hotspots' fuel surface & retreat) \\
- Stone mineralogy and cementing & Porosity / permeability of stone \\
\hline
\end{tabular}

Environmental cycling of temperature and moisture can act on building stones by the slow accumulation of stresses (fatigue) with the superimposition of higher magnitude events that have potential to impose 'acute' shock on the structure (McCabe et al. 2010a). Combinations of these stresses, either accumulated chronic background environmental stress over time or the additional input of an acute stress events, juxtaposed with decreasing stone strength (the ability of the stone to resist or withstand stress), can bring about rapid catastrophic change in stone. Potentially, this understanding facilitates a 'reading' of the long-term, as well as the immediate, causes of stone weathering by focusing on underlying causes and complexity.

While the holistic 'reading' of a façade in terms of understanding chronic and acute decay is possible, linking individual decay features to particular events or processes is much more difficult, because, as Cooke and Warren (1973) pointed out, features on the stone may not, in isolation, reveal the processes which produced them. However, there may be clues on a stone building that can tell of specific past events and are likely to have significant implications how the stone is behaving in the present day. Contemporary decay forms are thus brought about by a series of processes, creating a 'palimpsest' determined by the complex stress history of historic stone, and its subsequent exploitation by background environmental factors. 
It is beyond the scope of this paper, to summarise all environmental and mangenerated factors that can influence a stone building. The following sections explore some relevant factors, drawn from the previous research experience of the authors, highlighting examples from the various factors that can influence stone decay, leaving a trace for us to be read on building facades. These factors include environmental trends, pollution, punctuated decay agents and other elements beyond stone occurring in historic buildings.

\section{Reading past environmental trends from stone buildings}

Although anthropogenic factors are the most relevant cause for rapid decay of building stone, a myriad of built structures were lost before increasing pollution took place during industrialisation. Therefore, it cannot be forgotten that most weathering processes are controlled by natural background environmental conditions (Smith et al., 2008), and this is the context in which we need to set Anthropocene change.

The stone weathering system is made up of the complex interaction of material, form and environment. Background environmental processes provide the setting in which stone weathering, and human interactions with it, are to be understood. Much of our stone heritage has lived through significant environmental change that is concurrent to Anthropocene activity, and it is perhaps difficult to 'dis-entangle' the two. The past 2000 years alone have, for example, included fluctuation through the Roman Warm Period, Medieval Warm Period (MWP) and Little Ice Age (LIA). Figure 3 (from Swindles 2006) shows a water table reconstruction as a record of effective precipitation from Slieveanorra bog, County Antrim (Northern Ireland). The record indicates changes in the relative oceanicity / continentality related to changes in precipitation and temperature. The Roman Warm period and the LIA are marked, 
although evidence for the medieval warm period is more uncertain. The small square signifies the start of the climate deterioration of the middle ages, while the triangle marks the beginning of the last pulse of the LIA.

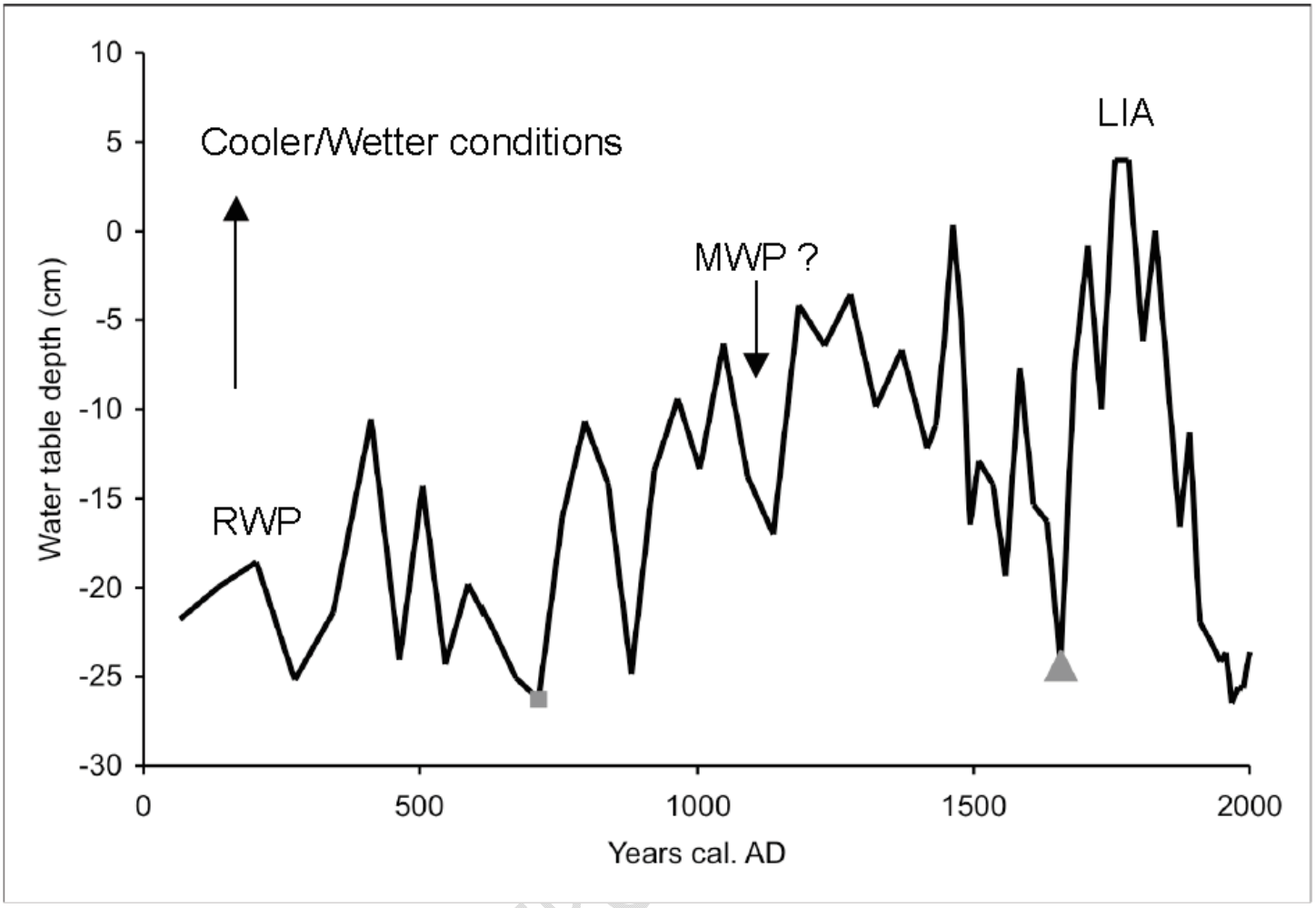

Figure 3: Water table reconstruction as a record of effective precipitation from Slievanorra Bog, County Antrim (from Swindles 2006)

RWP $=$ Roman Warm Period, MWP = Medieval Warm Period, LIA $=$ Little Ice Age

It has often been assumed that decay forms associated with frost events are angular (explained in Hall et al. 2002), where detachment has occurred as areas of stone have been 'wedged' off by the freezing and thawing of water (this appearance is seen in Figure 4). However, if forms of this nature are seen on historic façades they are often related to specific architectural features, and can often be equally attributable to salt weathering. It may be that, in a UK context at least, the 'memory' of past intense frost events (that are likely to have taken place, for example, during the Little Ice Age, c. 1590 - 1850) has disappeared through subsequent exploitation by salt weathering, or 
that frost events have not produced visible signs of decay (but rather contributed to the long-term deterioration of stone in a more 'intangible' way - see, for example, Warke 2007, McAllister et al. 2013).

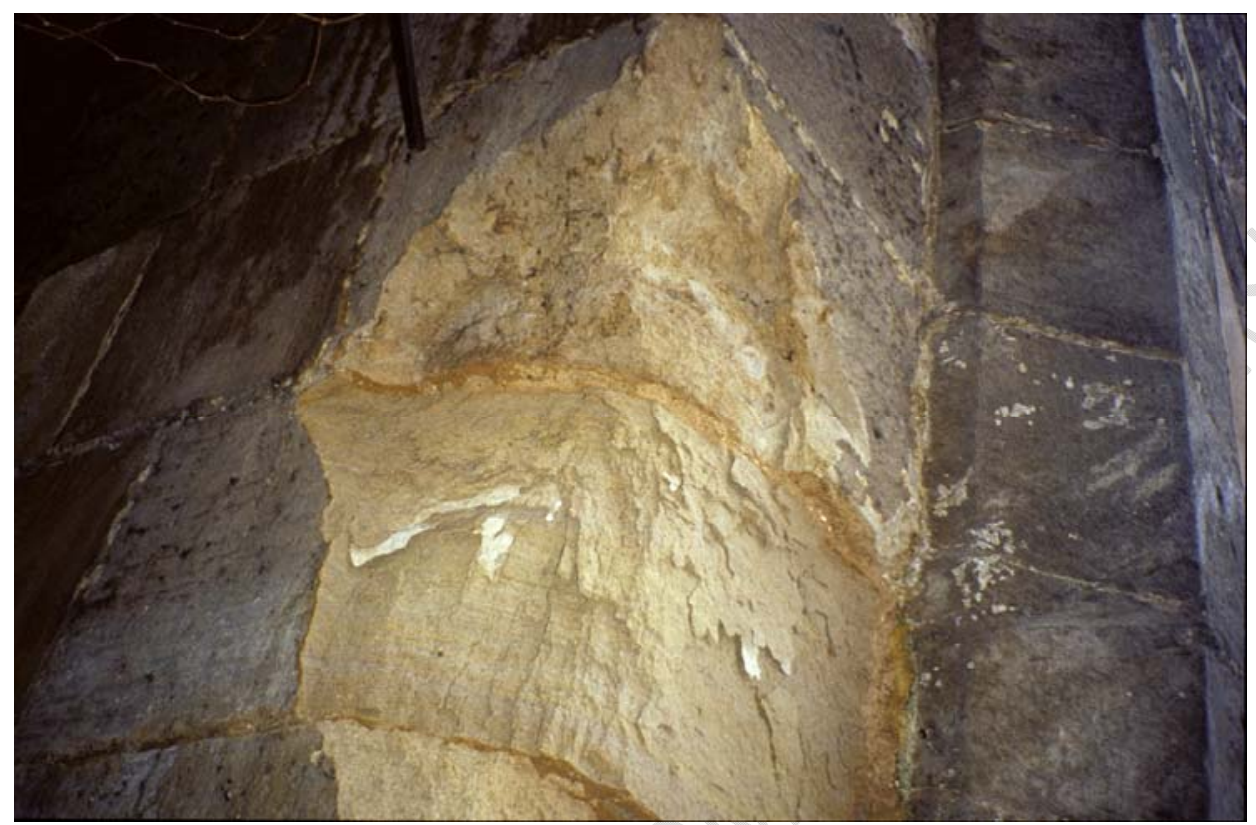

Figure 4:'Angular' decay forms in evidence at Charles Bridge, Prague.

Thus, building stone affected by freeze and thaw events tend to remain stable for long periods of time, during which isolated microcracks may appear. There is, however, a point when a critical threshold is reached and cracks grow rapidly leading to the above mentioned macroscopic angular cracks (Martinez-Martinez et al., 2013; FreireLista et al., 2015). Evidence of frost events may therefore be difficult to detect in stone (highlighting the importance of knowledge of local climate history). However, simulation experiments (McCabe et al. 2007a. Warke 2007, McAllister et al. 2013) have shown that frost events can have a subtle but significant impact on subsequent sandstone response to environmental cycling, encouraging accelerated breakdown when subjected to subsequent salt weathering. How stone responds to frost events will 
depend on stone strength - relatively fresh stone is likely to resolve stresses induced by single frost events, but in the context of a long and complex stress history (where stone may be significantly weakened over time), frost may bring about significant change in stone.

\section{Reading pollution patterns from stone buildings}

Pollution is quintessentially anthropogenic in character. Particulate deposition on stone buildings and leading to the development of gypsum black crusts have been, and in many cases remain, a problem of great importance in relation to the conservation of cultural heritage. Gypsum black crusts are the main product of the interaction between atmospheric sulphur and Ca-bearing materials (mainly limestone, but also other stone types and mortars). Gypsum nucleates around pollution particulates (e.g. Novakov et al, 1974, Del Monte et al 1984, Rodriguez-Navarro and Sebastian, 1996) engulfing them to generate a black crust (see Figure 5). However, these deposits are also an important resource for the study of the evolution of air pollution patterns in the past because, as referred below, their stratigraphic analysis (as a palimpsest) provides information about the development of pollutants regardless of the existence of direct historic pollution data.

In 1932, Schaffer stated that "the question of atmospheric pollution has such important bearings on the decay of building stones that it is considered desirable to discuss it in greater detail" (p.25), but it was not until the 1980s, when the consideration of the deposits of air pollution and the variability of its chemical composition over time as one of the main agents of deterioration of buildings became a widely studied research priority (Del Monte et al, 1981; Camuffo et al, 1982, 1983, Brimblecombe, 1987). 


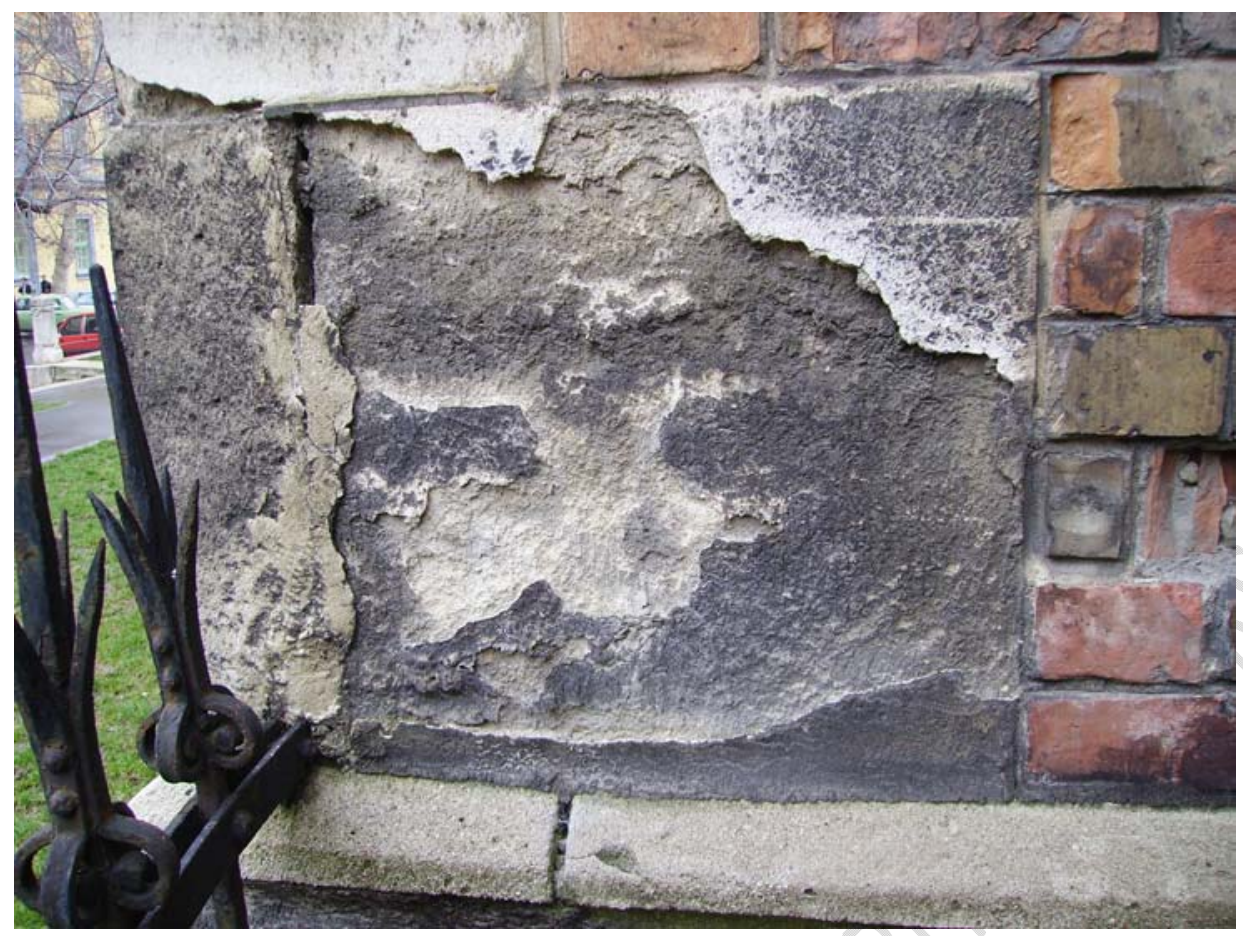

Figure 5: Black crusts in a historic building in Budapest (Hungary). This example shows successive episodes of encrusting and spalling through the recent history of this building, with the last encrustation episodes being less effective in terms of surface stabilization.

The study of the relationship of air pollution and built heritage was incorporated into policy action by the European Union through the 'Recommendation for sustained care of the cultural heritage against physical deterioration due to pollution and other similar factors' (1997/2 Council of Europe). In recent years the importance of analyzing the different compositions of these deposits began to be recognized (Brimblecombe and Grossi 2006; Ghedini et al 2006; Bonazza et al 2005; Siegesmund et al, 2007). Since then, heavy metals, as well as other components such as polyaromatic hydrocarbons, and other products of the Anthropocene, have been widely studied as indicators of pollutants sources and as a tool for understanding the evolution of the composition of pollutants over time (Török et al., 2011; Belfiore et 
al., 2013; La Russa et al., 2013; Ozga et al., 2014; Barca et al., 2014; Ruffolo et al., 2015).
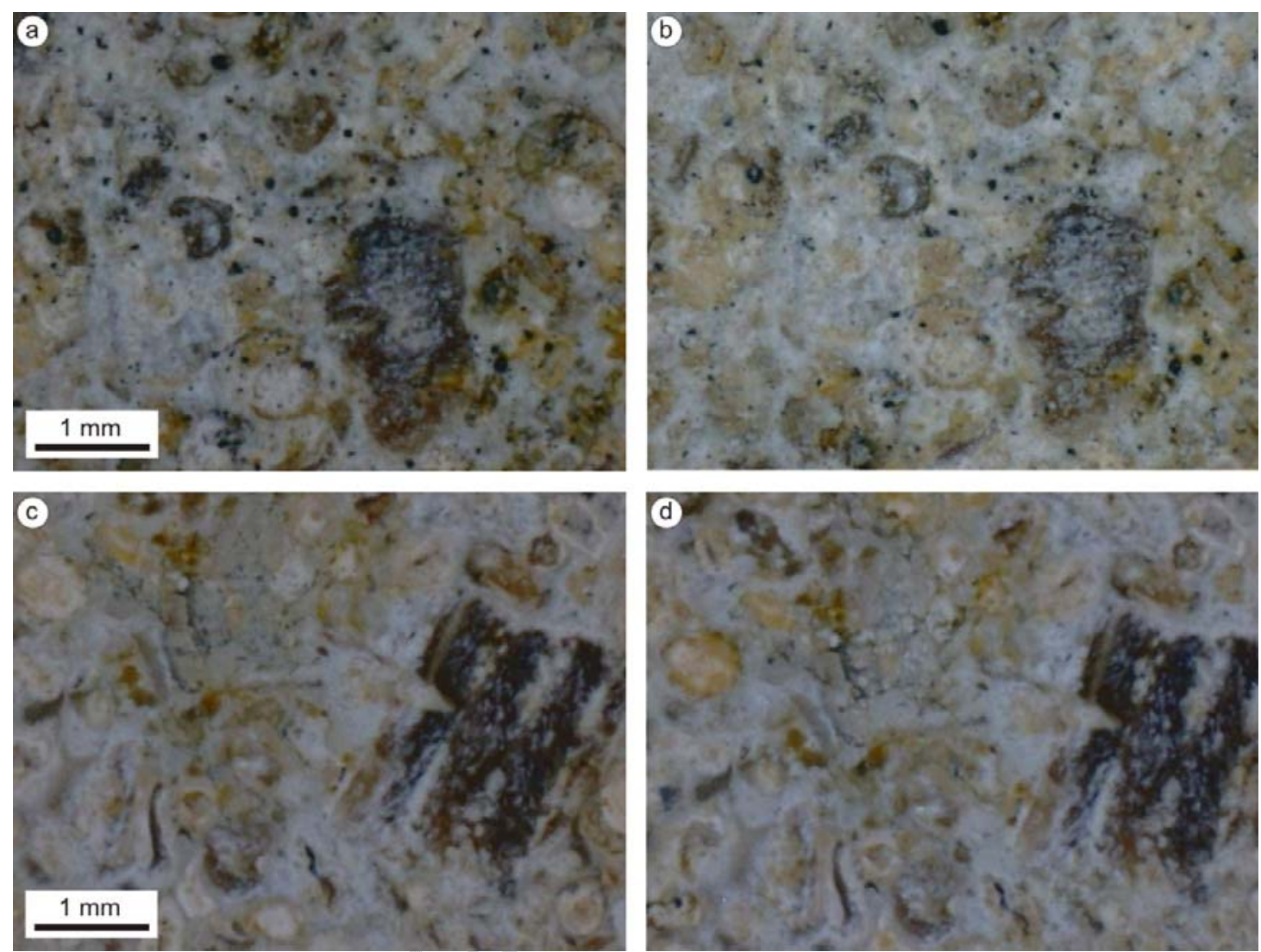

Figure 6: Jurasic oosparite (Stoke Ground) used historically as a building stone in Oxford before (a, c) and after being subject artificially for 9 days to a flowing $\mathrm{SO}_{3}$ atmosphere with particulates (b) and flowing $\mathrm{SO}_{3}$ without particulates (d). Gypsum (white residue on the top) develops more effectively in the presence of particulates (b), while dissolution takes place (d) in absence of particulates.

Black crusts, as with other artificial surface crusts, tend to cause detachment of the stone surface over time, exposing a new surface to pollution (Figure 3). Experiments by Gomez-Heras et al. (2008b) in which stone samples were subject to flowing $\mathrm{SO}_{3}$ with and without particulate matter (Figure 6) showed that a reduction in the available amount of particulate matter in the air may discourage the formation of gypsum and enhance dissolution, stressing the catalyst effect of particulates not only for the $\mathrm{SO}_{2}$ 
$\rightarrow \mathrm{SO}_{3}$ reaction (as suggested by e.g. Novakov et al., 1974 and Rodriguez-Navarro and Sebastian, 1996), but also for gypsum surface crystallization itself. While gypsum crusts can be extremely hazardous for building stone, they also reduce the surface reactivity of calcite, which otherwise would dissolve under acid attack (Wilkins et al. 2001, 2002). This highlights the need to consider how stone decay may evolve in a future 'cleaner' (i.e. less rich in particulates) urban environment.

\section{Reading historical fire in stone}

In addition to background environmental factors and wider pollution trends, weathering agents may act in a stochastic and punctuated fashion. Fire is a distinctive punctuated weathering agent, and it is specifically emphasised in this paper because some consider the mastery of fire as a defining point in the onset of Anthropocene (Glikson 2013), and also an agent which is likely to become more difficult to manage in the future, as associated with climate change (Bowman et al., 2009). This intensifies the already serious risk of fire to stone-built heritage (Maxwell 2008). In addition to this, the present context in which hundreds of heritage properties are threatened by terrorism and warfare, make this agent especially relevant.

Fire is likely to be a very significant event in the history of a stone structure (as well as shaping the behaviour of rocks in natural landscapes), and is a constant threat to stone-made cultural heritage (Gomez-Heras et al., 2009). It can have immediate, acute, 'shock' effects, due to differential thermal expansion triggered by compactness (Gomez-Heras et al., 2006b, 2006c) and mineral composition (Vazquez et al., 2015), fracturing stone and causing spalling and catastrophic loss of material. Other inherent factors, like moisture content within the stone pore system, may lead to further cracking through rapid expansion of water (Dorn 2003). Equally importantly, a single 
fire event has the potential to shape the subsequent performance of a stone façade for many years, by influencing patterns and rates of decay due to the exploitation of weaknesses (for example, micro-fracture networks) inherited from the fire event, by background environmental factors like salt weathering (McCabe et al. 2010b).

If a fire has occurred recently then blackening of stone is the most blatant 'memory' effect and associated feature on the surface. While studies simulating fire with furnace-heating have rightly highlighted the discolouration of building stone (Hajpal and Török 2004) with a peak at around $600{ }^{\circ} \mathrm{C}$ (Kompanikova et al., 2014), the fire experiments reported by McCabe et al. (2007) make it clear that the soot cover is an important by-product of fire, and the most obvious immediate surface effect. This soot cover brings with it the possibility of reduced permeability and hydrophobic tendencies, influencing subsequent exploitative weathering processes. The surface soot-cover following a fire can promote surface / subsurface heterogeneity and can result in detachment of the artificial surface crust in the form of flaking or scaling, when salt concentrates and crystallizes beneath the surface (Gomez-Heras et al. 2009, McCabe et al 2010b). After the soot layer has detached in this way (or perhaps been removed by cleaning), the exposed surface can exhibit rapid granular disaggregation caused by alteration of the sandstone matrix by the extreme heat of the fire (McCabe et al. 2010b). Other 'memory' effects caused by fire are the reddening / pinking of blocks due to the oxidation of iron (if present) in the cement, and the associated collapse of clay minerals which reduce the overall cohesion of the stone (GomezHeras et al. 2004). Thus, fire-induced chemical alteration can weaken stone and may facilitate the ingress of moisture along planes of weakness. Three-dimensional networks of fracturing may also be seen as the result of fire caused by thermal shock 
in combination with differential expansion of adjoining materials (for example, soft sandstone / rigid mortar).

\section{Recording beyond stone: other elements associated with stonework}

Stone rarely appears on its own in a heritage structure, but is often accompanied by mortars or other components that influence stone behaviour. Lime mortar is also a useful tool to read past climates, as local climate conditions (especially moisture and $\mathrm{CO}_{2}$ ) affect the evolution of binder morphology and the mineralogy of historic lime mortars (Dotter, 2010). Moisture and carbonation speed determine, for example, the formation of Liesegang patterns in mortars (Rodriguez-Navarro et al., 2002; Elert et al, 2002).

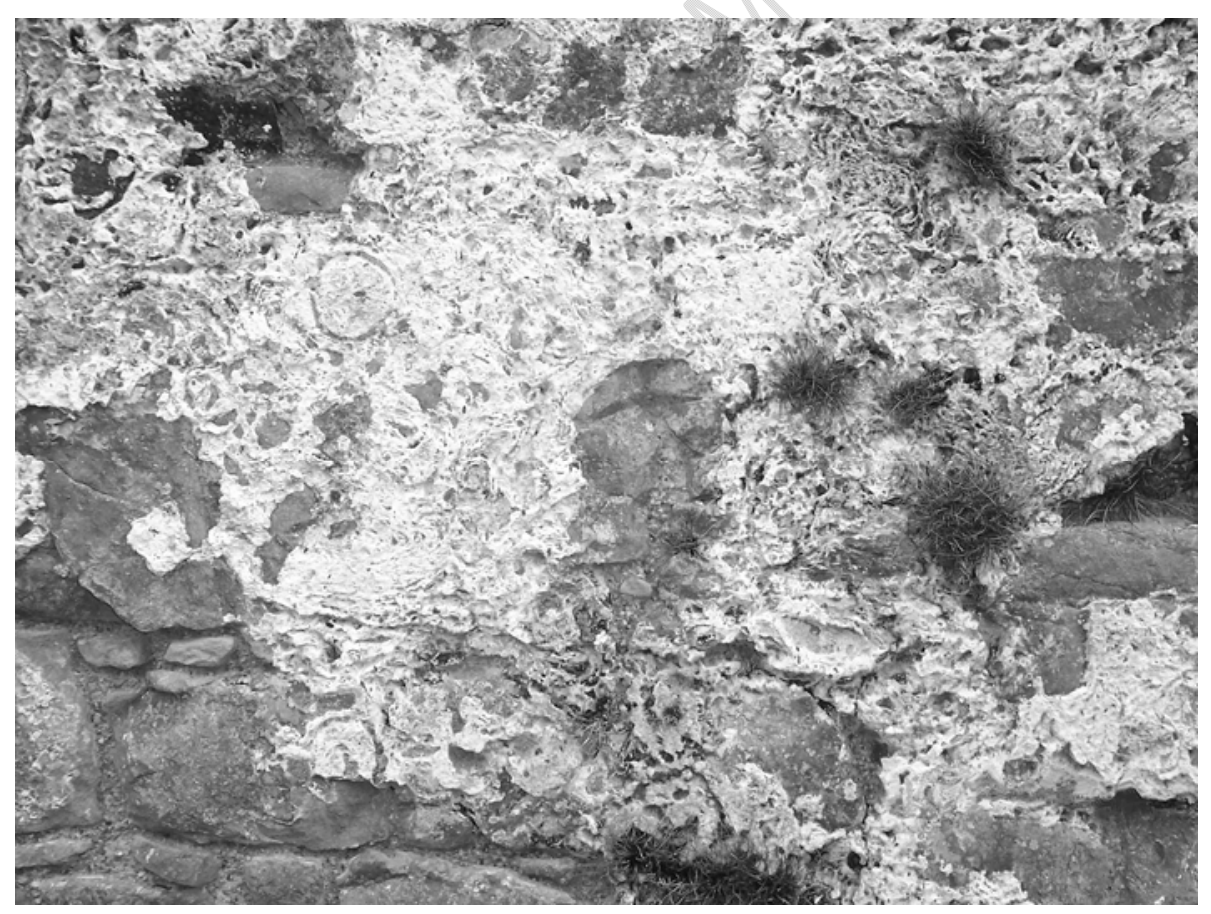

Figure 7: Medieval mortar remains at Bonamargy Friary where Liesegang patterns can be observed. 
Lime rendering (the application of a lime putty to stone for protective or aesthetic purposes) has been a relatively common practice since the first century AD to the present day as a major component of construction (Ashurst 1983). Lime rendering is then a recurring feature of human interaction with stone and it may be that remnants of the historic render are still attached to a façade (as in Figure 7). Clearly, being able to see the remnants of a lime render will aid in 'reading' the stress history of a façade, in which the impact of lime rendering and the decay of that render over time, constitute a potentially important process. It may be controversial to class lime render as a potential inducer of stress in stone. However, laboratory research suggests that when lime rendering falls off due to neglect, the stone can retain the physical 'memory' of the change to its surface, with implications for long-term behaviour and the potential to induce stress in combination with other environmental factors. Physically, surface permeability is likely to have been reduced by rendering (and the residue left after the render has fallen off), hindering moisture ingress and egress, and compromising the ability of the stone to 'breathe' freely (Smith et al. 2001, McCabe et al. 2006). This can provide an initial protection to the stone surface, lending integrity to grain boundaries and hindering exploitative decay processes like salt weathering and freeze-thaw. However, this initial protection masks the risk of subsequent accelerated decay. Chemically, the stone is likely to have become 'loaded' with a calcium-rich solution from the lime render (making the near-surface zone susceptible to the formation and action of calcium salts), and (combining physical and chemical effects) soluble salts can become trapped in the substrate because the lower surface permeability can interfere with the natural drying process, i.e. evaporation through the stone surface (see, for example, McCabe et al. 2006, Young 2006). As a result, salt 'hotspots' can develop at depth in porous stone blocks, which can fuel the 
rapid catastrophic surface retreat so often evidenced on historic sandstone structures (Smith et al 2002). If blocks are rapidly retreating on an historic façade, even if there is no visual evidence of lime rendering, this may be a potential contributing factor.

As discussed elsewhere, during the 19th Century the increasing concern on building stone conservation was coupled to the increasing rate of deterioration inflicted on the stone heritage. This time also witnessed a drift from traditional conservation treatments to newly developed materials. Lime was gradually abandoned in favour of cements (Varas et al. 2005) and traditional protective treatments like "patinas" were substituted by other synthetic coatings (Vazquez-Calvo et al. 2007). Several synthetic treatments are known to lead to negative effects in terms of conservation due to, for example, their discoulouration and they can be a major cause of damage to historic masonry buildings (Chiantore and Lazzari 2001; Rodrigues da Costa and Rodrigues 2011; Perez-Ema et al., 2014).

Therefore, the increasing need of preserving stone-built heritage during the $19^{\text {th }}$ and early $20^{\text {th }}$ century was often coupled to an increasing rate of inappropriate conservation. Past conservation treatments could be then considered as yet another "anthropocenic" agent in the context of building stone decay.

Because of its disruptive nature, inappropriate conservation interventions may also difficult extremely 'reading' other more subtle past events and need to be taken into account when reading a building, as their presence may have deeply conditioned the evolution of weathering, for example, creating impermeable barriers that lead to modifying decay patterns (Varas et al. 2007, Varas-Muriel et al. 2015). The risks of this newer "anthropocenic" agent for stone decay continue today with the popularisation of new materials in conservation, such as nanolimes, whose future 
behaviour is still under consideration (Giorgi et al. 2000, Daniele et al. 2008, Arizzi et al. 2015)

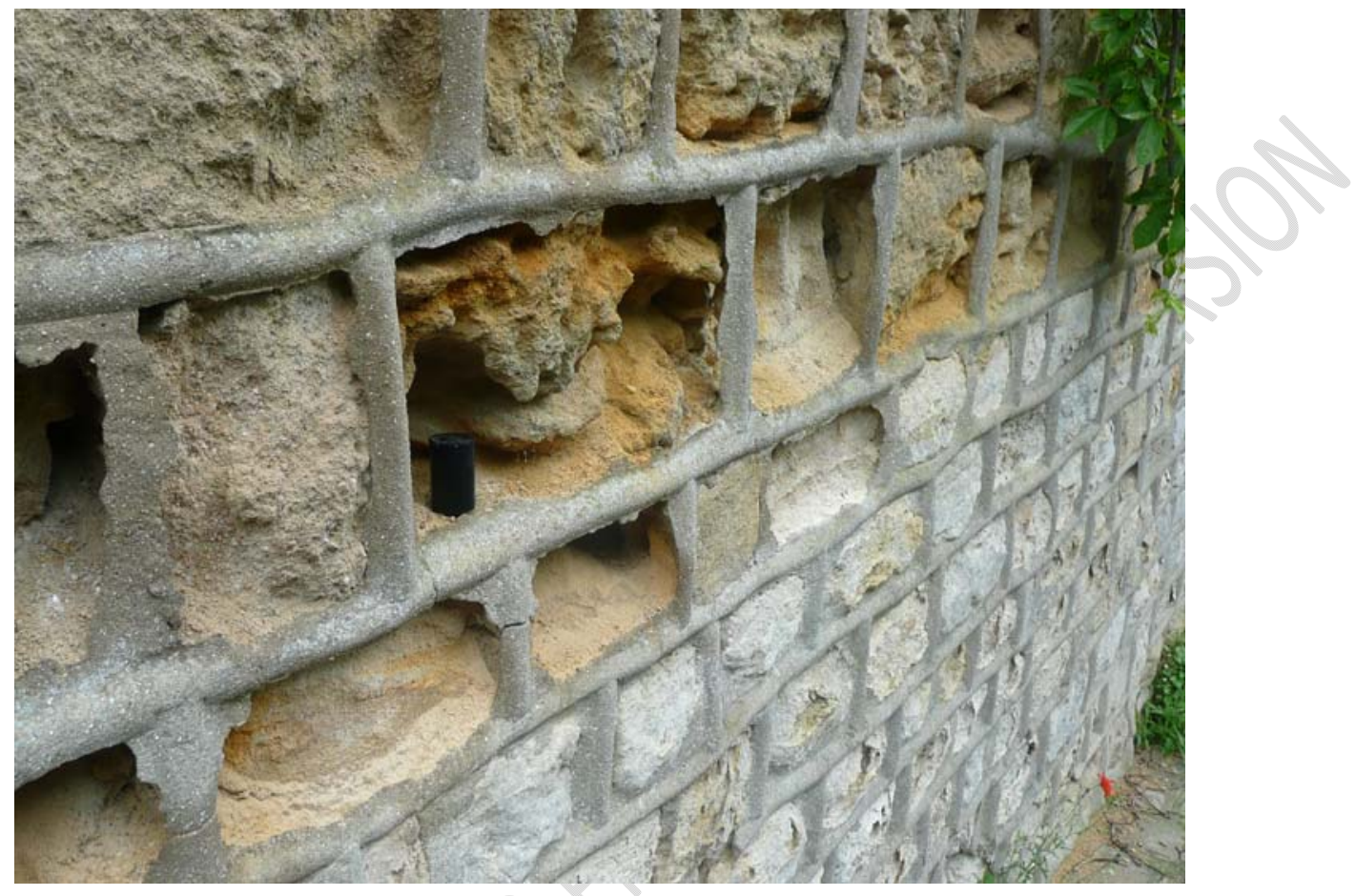

Figure 8: Boxwork in a stone wall at Auvers, France.

One common and obvious sign of inappropriate intervention on stone structures is the phenomenon of 'boxwork' (Figure 8), where rigid modern mortar, incompatible with softer sandstone walling, has caused surface retreat of sandstone by encouraging moisture to gather on the stone surface, eventually leaving the mortar to protrude from the façade. Often related to 'boxwork' are impermeable mortars (often Portland cement) that force moisture and soluble salts through the stonework (rather than draining through the mortar network), causing accelerated breakdown of the stone. A similar effect occurs when mis-matched materials are placed in a façade alongside one another (Figure 9). Another unfortunate sign of mis-conservation is the 
mechanical fracturing and chemical staining of stone by the corrosive decay of iron dowels inserted into stonework, or the mobilization of elements within the stone as a result of inappropriate chemical cleaning.

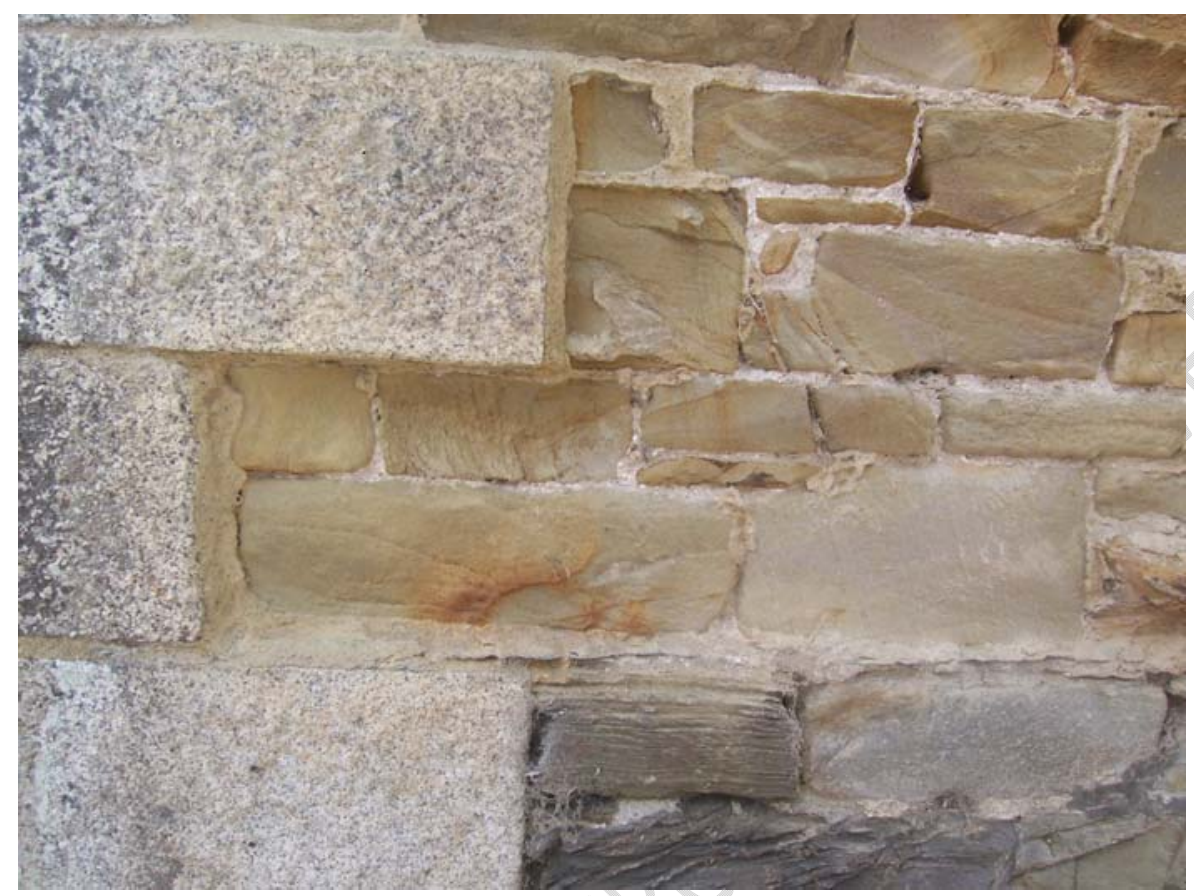

Figure 9: Inappropriate juxtaposition of materials causing severe surface loss at Glendurgan Garden, Cornwall, England

All previously discussed factors, their associated features seen in stone, and their implications for the long-term behaviour of stone, are summarised in Table 2.

Table 2: Potential stress-inducing events, associated features and potential role in long term behaviour of stone.

\begin{tabular}{|c|c|c|}
\hline Decay Factor & Associated features & $\begin{array}{l}\text { Potential role in long term } \\
\text { behaviour of stone }\end{array}$ \\
\hline Black crusts & $\begin{array}{l}\text { - } \text { Deposits grow } \\
\text { - } \text { Reduced surface } \\
\text { permeability } \\
\text { - } \\
\text { Accumulation of salts } \\
\text { behind the crust }\end{array}$ & $\begin{array}{l}\text { While stabilizing } \\
\text { surfaces when growing, } \\
\text { their detachment } \\
\text { exposes a weakened } \\
\text { underlying surface } \\
\text { which may decay }\end{array}$ \\
\hline
\end{tabular}




\begin{tabular}{|c|c|c|}
\hline & $\begin{array}{l}\text { Weakening of } \\
\text { underlying layers } \\
\text { - Migration of heavy } \\
\text { metals towards the stone }\end{array}$ & $\begin{array}{l}\text { catastrophically if a new } \\
\text { black crust does not } \\
\text { stabilize it. }\end{array}$ \\
\hline Frost & $\begin{array}{l}\text { Potentially angular } \\
\text { features, but frost may } \\
\text { not have unique } \\
\text { diagnostic decay } \\
\text { features } \\
\text { - Stone grains gathered at } \\
\text { base of wall }\end{array}$ & $\begin{array}{l}\text { - Intangible weakening of } \\
\text { stone, often not visible } \\
\text { to unaided eye } \\
\text { - } \quad \text { Exploitation of inherited } \\
\text { weakness by salt } \\
\text { weathering, background } \\
\text { environmental cycling }\end{array}$ \\
\hline Fire & $\begin{array}{ll}\text { - } & \text { Soot } \\
\text { - } & \text { discolouration } \\
& \text { (oxidation) } \\
\text { - } & \text { Hydrophobicity } \\
\text { - } & \text { Fracturing and spalled } \\
& \text { corners } \\
\text { - } & \text { Loss of stone strength } \\
\end{array}$ & $\begin{array}{l}\text { - Exploitation of inherited } \\
\text { weakness by salt } \\
\text { weathering, background } \\
\text { environmental cycling }\end{array}$ \\
\hline Lime render / removal & $\begin{array}{l}\text { - } \begin{array}{l}\text { Remains of lime render } \\
\text { may be visible }\end{array} \\
\text { - } \\
\text { Reduced surface } \\
\text { permeability } \\
\text { - } \\
\text { Calcium-rich near } \\
\text { surface zone }\end{array}$ & $\begin{array}{l}\text { - Reduced surface } \\
\text { permeability traps salts } \\
\text { in stone interior and } \\
\text { causes heterogeneity } \\
\text { - } \begin{array}{l}\text { Potential for formation } \\
\text { of calcium salts }\end{array}\end{array}$ \\
\hline Inappropriate conservation & $\begin{array}{l}\text { - 'Box work' } \\
\text { - Iron fixings in stone } \\
\text { - Impermeable surface } \\
\text { treatments }\end{array}$ & $\begin{array}{l}\text { - 'Box work' forces } \\
\text { moisture through soft } \\
\text { stone faces } \\
\text { - Physical damage } \\
\text { through swelling of } \\
\text { fixings and chemical } \\
\text { corrosion } \\
\text { - Trapping of moisture } \\
\text { and salt in stone interior } \\
\text { - Exploitation by } \\
\text { background } \\
\text { environmental cycling }\end{array}$ \\
\hline
\end{tabular}

\section{Anticipating the future: the next challenge?}

What is the next superimposition on the historic façade-as-palimpsest? Climate change is another defining feature of the Anthropocene, where human activity has perhaps irrevocably altered the 'natural' atmosphere. This follows the long history of 
interactions between humans and stone heritage, many of which have been outlined above. But, as Mol and Viles (2012) state, monuments are still deteriorating at an alarming rate despite our increasing knowledge on decay factors, which highlights the need of being able to understand the evolution of this "palimpsest" to anticipate future weathering trends. For example, when 'climate change' is mentioned in the context of stone weathering processes, many assume that temperature effects will bring about the most severe damage (Bonazza et al., 2009b). However, it is the response of many natural stone structures to trends in oceanic climates towards wetter conditions (especially in winter months) that is already becoming apparent to many building owners and architects. As an example, projected climate change scenarios for the UK (especially the northwest) suggest that winters will become increasingly wet through the next century. More prolonged wetting of stone structures is likely to lead to a change in moisture regimes and the patterns and mechanisms of decay that act on stone (Smith et al. 2011a, McCabe et al. 2013a, McCabe et al. 2015) - this is indicated by research deploying experimental exposure walls (McAllister 2014, McCabe et al. 2013b). Traditional views of environmental cycling involve the periodic wetting and drying of the stone surface - cycling that drives the disaggregation of the surface by the repeated crystallisation and hydration/dehydration of salts. However, longer periods of winter rainfall (spreading into spring and autumn) have been shown to bring about 'deep wetting' of natural stone. The knock-on effects for salt weathering mechanisms are potentially dramatic, with salts penetrating much more deeply into stone with the deeper wetting front, and also being transported throughout blocks by ion diffusion where block saturation occurs for prolonged periods of time (McCabe et al. 2013b). Patterns of salt distribution through stone blocks may significantly alter as a result. If/when complete 
drying out of blocks does eventually happen (in summer months, for example) crystallization damage may be much more widespread, especially in causing damaging subflorescences in the block interior. Add to this the potential of increased colonization of blocks surfaces by algae due to increased moisture supply and warmer conditions (Cutler and Viles 2010) - bringing with it aesthetic, chemical and physical implications- and the challenge facing weathering scientists becomes even more substantial. As explored by McCabe et al. (2015), surface modification brought about by damp conditions, for example, algal growth can have implications for the stone subsurface. This would happen where interference with natural drying (due to reduced surface permeability) is likely to encourage the accumulation of moisture in blocks over time. Thus, hindering drying and impacting on subsurface salt distribution (potentially leading to the damaging subflorescences mentioned above).

There are not, however, studies of this type in other climatic regions in which increased temperatures and decreased precipitation are expected, as for example in Mediterranean climates. Mediterranean continental climate projections foresee a trend toward a 'tempered climate' (Del Rio González, 2005) with warmer winters and cooler summers. Climate change and altered rainfall patterns and temperatures will also affect changes in groundwater levels above and under the conditions of moisture absorption, freezing and drying of materials in contact with the ground. These ranges of condition will inevitably have an impact on the character of stone materials.

It should be remembered, however, that challenges associated with climate change (regardless of location) should be set in the context of the long and complex history of events that has preceded them. 


\section{Conclusions}

The widespread use of the term 'Anthropocene' marks a milestone in the evolution of earth sciences, in which research is focusing on mutual impacts between earth systems and society. The study of stone built heritage decay is highly relevant to this, epitomising the complex interrelations between human activity and the earth system. Stone-built heritage is, firstly, an asset to preserve, and in the present context of climate change, its preservation faces new threats and challenges to be analysed from an Anthropocenic perspective. Secondly (but often overlooked), stone-built heritage is a recorder of past and present environmental changes, and can be used as a proxy to understand how environment and the effects of human activity have evolved over the lifetime of a building (through the use of stone by society to the ways in which society impacts on stone weathering). This exemplifies a picture of the Anthropocene as a time of mutual impacts between humans and the Earth system, where each influences the behaviour of the other.

A natural stone landscape (whether in the natural or built environment) is not a 'clean' pure product of contemporary processes, but it has a background of residual effects of earlier stresses, many of which are human-induced. The accurate 'reading' of complex messages left by past events or human interactions either on a landscape or a stone façade is a necessary foundation for understanding the processes that have shaped stone through the Anthropocene. Common events that may be 'read' on a façade are the effects of neglect and removal of lime rendering, fire, frost, inappropriate conservation and background environmental factors - along with the interactions between them. Building stones, as palimpsests, experience more 'overlain' events, more complex stress histories, uncertainty in predicting stone behaviour increases. The long-term decay of historic stone is often characterized by 
punctuated stress events that are superimposed on background environmental factors - this understanding provides a framework in which to 'read' the long-term, as well as the immediate, events that have influenced the behaviour of stone.

\section{Acknowledgements}

[BLIND]

\section{References}

Amoroso, G.G., Fassina, V., 1983. Stone decay and conservation: atmospheric pollution, cleaning, consolidation, and protection. Materials science monographs 11. Elsevier, Amsterdam, xix, 453 pp.

Arizzi, A., Gomez Villalba, L.S., Lopez-Arce Martinez, P., Cultrone, G., Fort, R., 2015. Lime mortar consolidation with nanostructured calcium hydroxide dispersions: the efficacy of different consolidating products for heritage conservation. European Journal of Mineralogy 27: 311-323.

Ashurst, J., 1983. Mortars, Plasters and Renders in Conservation. Ecclesiastical Architect's and Surveyor's Association, London.

Barca, D., Comite, V., Belfiore, C.M., Bonazza, A., La Russa, M.F, Ruffolo, S.A., Crisci, G.M., Pezzino A., Sabbioni, C., 2014. Impact of air pollution in deterioration of carbonate building materials in Italian urban environments. Applied Geochemistry 48, 122-131.

Belfiore, C.M., Barca, D., Bonazza, A., Comité, V., La Russa, M.F., Pezzino, A., Ruffolo, S.A., Sabbioni, C., 2013. Application of spectrometric analysis to the identification of pollution sources causing cultural heritage damage. Environmental Science and Pollution Research 20, 8848-8859. 
Benavente, D., Brimblecombe, P., Grossi, C.M., 2008. Salt weathering and climate change. In: Colombini, M.P., Tass, L. (eds.) Trends in Analytical, Environmental and Cultural Heritage Chemistry, TSN Trivandrum.

Beschel R., 1950. Flechten als Altersmasstab rezenter Moränen. Zeitschrift für Gletscherkunde und Glazialgeologie 1: 152-161.

Beven, K., 1996. Equifinality and uncertainty in geomorphological modelling, in B. L. Rhoads, C. E. Thorn, The Scientific Nature of Geomorphology, Wiley \& Sons, New York. $289-313$.

Bloodworth, A.J., Scott, P.W., McEvoy, F.M., 2009. Digging the backyard: mining and quarrying in the UK and their impact on future land use. Land Use Policy $26,317-325$

Bonazza A, Sabbioni C, Ghedini N., 2005. Quantitative data on carbon fractions in interpreting black crusts and soiling on European built heritage. Atmospheric Environment Environ, 39, 2607-2618.

Bonazza, A., Messina, P., Sabbioni, C., Grossi, C.M., Brimblecombe, P., 2009a. Mapping the impact of climate change on surface recession of carbonate buildings in Europe. Science of the Total Environment 407(6), 2039-2050.

Bonazza, A., Sabbioni, C., Messina, P., Guaraldi, C., De Nuntiis, P., 2009b. Climate change impact: Mapping thermal stress on Carrara marble in Europe. Science of The Total Environment 407 (15), 4506-4512.

Bowman, D.M.J.S., Balch, J.K., Artaxo, P., Bond, W.J., Carlson, J.M., Cochrane, M.A., D'Antonio, C.M., DeFries, R.S., Doyle, J.C., Harrison, S.P., Johnston, F.H., Keeley, J.E., Krawchuk, M.A., Kull, C.A., Marston, J.B., Moritz, M.A., Prentice, I.C., Roos, C.I., Scott, A.C., Swetnam, T.W., Van Der Werf, G.R., Pyne, S.J., 2009. Fire in the earth system. Science 324 (5926), 481-484 
Brimblecombe, P., 1987. The Big Smoke: A History of Air Pollution in London since Medieval Times. Methuen \& Co, London. 185 p.

Brimblecombe, P., Camuffo, D., 2002. Long term damage to the built environment. In: Brimblecombe $\mathrm{P}$ (Ed.) The Effects of Air Pollution on the Built Environment. Air Pollution Reviews - Vol. 2. Imperial College Press, London. pp. $1-30$

Brimblecombe, P., Grossi, C.M., 2006. Climate change critical to cultural heritage. In: Heritage, Weathering and Conservation, Fort R, Alvarez De Buergo M, Gomez-Heras M, Vazquez-Calvo C (Eds.) Taylor \& Francis, London, pp 387393.

Brimblecombe, P., Grossi C.M., 2007. Damage to Buildings from Future Climate and Pollution. American Preservation Technology Bulletin 38,13-19.

Camuffo, D., Del Monte, M., Sabbioni, C., Vittori, O., 1982. Wetting, deterioration and visual features of stone surfaces in an urban area. Atmospheric Environment 16, 2253-2259.

Camuffo, D., Del Monte, M., Sabbioni, C., 1983. Origin and growth mechanisms of the sulfated crusts on urban limestone. Water, Air and Soil Pollution 19, 351359.

Carcavilla Urqui, L., 2012. Geoconservación. Catarata, Madrid. 126p.

Chiantore, O., Lazzari, M., 2001. Photo-oxidative stability of paraloid acrylic protective polymers. Polymer 42, 17-27.

Colette, A., 2007. Case studies on Climate Change and World Heritage. UNESCO World Heritage Centre, Paris.

Cooke, R.U., 1989. Geomorphological contributions to acid rain research: studies of stone weathering. Geographical Journal 155,361-366. 
Cooke, R.U., Warren, A., 1973. Geomorphology in Deserts. Batsford, London. iii-xii, 394, $30 \mathrm{pp}$.

Crutzen, P., Stoermer, E., 2000. The Anthropocene, Global Change Newsletter, No. $41,17-18$

Cutler, N., Viles, H., 2010. Eukaryotic Microorganisms and Stone Biodeterioration, Geomicrobiology Journal 27(6), $630-646$.

Daniele, V., Taglieri, G., Quaresima, R., 2008. The nanolimes in Cultural Heritage conservation: Characterisation and analysis of the carbonatation process. Journal of Cultural Heritage 9(3), 294-301.

De Thury, H., 1828. Sur le Procédé proposé par M. Brard pour reconnaître immediatement les pierres qui ne peuvent pas résister à la gelée, et que l'on désigne ordinairement par les noms de pierres gelives ou pierres gelisses. Annales de Chimie et de Physique, 38: 160-192.

Del Monte, M., Sabbioni, C., Vittori, O., 1981. Airbone carbon particulates and marble deterioration. Atmospheric Environment: 15, 645-652.

Del Monte M., Sabbioni C., Ventura A., Zappia G., 1984. Crystal growth from carbonaceous particulates. The Science of the Total Environment 36, 247-254.

Del Rio González, S., 2005. El cambio climático y su influencia en la vegetación de Castilla y León (España). Itinera geobotanica 16, 5-534

Doehne, E., Price, C.A., 2010. Stone conservation: an overview of current research 2nd ed. Getty Publications, Los Angeles.

Dorn, R.I., 2003. Boulder weathering and erosion associated with a wildfire, Sierra Ancha Mountains, Arizona. Geomorphology 55, 155 - 171

Dotter, K.R., 2010. Historic lime mortars: potential effects of local climate on the evolution of binder morphology and composition. In: Smith, B. J., Gomez- 
Heras, M., Viles, H.A, Cassar, J., (eds) Limestone in the Built Environment: Present-Day Challenges for the Preservation of the Past. Geological Society, London, Special Publications, 331, 119-126.

Elert, K., Rodriguez-Navarro, C., Sebastian Pardo, E., Hansen, E., Cazalla, O., 2002. Lime mortars for the conservation of historic buildings. Studies in Conservation $47(1), 62-75$.

Erlandson, J.M., Braje, T.J., 2013. Archeology and the Anthropocene. Anthropocene 4: $1-7$.

Finney, S.C., 2014. The 'Anthropocene' as a ratified unit in the ICS International Chronostratigraphic Chart: fundamental issues that must be addressed by the Task Group. In: Waters, C.N., Zalasiewic, J.A., Williams, M., Ellis, M.A., Snelling, A.M., 2014. A stratigraphical basis for the Anthropocene. Geological Society, London, Special Publications, 395, 23-28.

Freire-Lista, D.M., Fort, R., Varas-Muriel, M.J., 2015 Freeze-thaw fracturing in building granites. Cold Regions Science and Technology 113, 40-51.

Garcia-Rodriguez, M., Garcia-Rodriguez, M., Gomez-Heras, M., 2015. Sierra de Guadarrama (Madrid, Spain): bridging the gap between geology and architecture. In: Přikryl, R., Török, A., Gomez-Heras, M., Miskovsky K. \& Theodoridou, M. (eds.) Sustainable Use of Traditional Geomaterials in Construction Practice. Geological Society, London, Special Publications, 416,

Geikie A (1887) The Scenery of Scotland Viewed in Connection with its Physical Geography. Second Edition. McMillan and co, London.

Ghedini, N., Sabbioni, C., Bonazza, A., Gobbi, G., 2006. Chemical-thermal quantitative methodology for carbon speciation in damage layers on building surfaces. Environmental Science Technology 40, 939-944. 
Giorgi, R., Dei, L., Baglioni, P., 2000. A new method for consolidating wall paintings based on dispersion of lime in alcohol. Studies in Conservation, 45. 154-161

Glikson, A., 2013. Fire and human evolution: The deep-time blueprints of the Anthropocene. Anthropocene 3, 89-92.

Gomez-Bolea, A., Llop, E., Arino, X., Saiz-Jimenez, C., Bonazza, A., Messina, P., Sabbioni, C., 2012. Mapping the impact of climate change on biomass accumulation on stone. Journal of Cultural Heritage 13(3): 254-258.

Gomez-Heras, M., Fort, R., 2004. Location of quarries of non-traditional stony materials in the architecture of Madrid: The Crypt of the Cathedral of Santa María la Real de la Almudena. Mater. Construcc., 54 (274), 31-47.

Gomez-Heras, M., Varas, M.J., Alvarez de Buergo, M., Fort, R., 2004. Characterization of changes in matrix of sandstones affected by historical fires. In: D Kwiatkowski, R Löfvendahl (Eds.). 10th International Congress on Deterioration and Conservation of Stone - Stockholm 2004. pp. 561-568.

Gomez-Heras, M., Smith, B.J., Fort, R., 2006a. Surface temperature differences between minerals in crystalline rocks: Implications for granular disaggregation of granites through thermal fatigue. Geomorphology 78(3-4), 236-249

Gomez-Heras, M., Figueiredo, C., Varas, M.J., Maurício, A., Alvarez de Buergo, M., Aires-Barros, L., Fort, R., 2006b. Digital image analysis contribution to the evaluation of the mechanical decay of granitic stones affected by fires. In: S.K. Kourkoulis (Ed.) Fracture and failure of natural building stones. Springer, Dordrecht.: pp. 427-437.

Gomez-Heras, M., Hajpál, M., Alvarez de Buergo, M., Török, A., Fort, R., Varas, M.J., 2006c. Evolution of porosity in Hungarian building stones after simulated burning. In: R. Fort, M. Alvarez de Buergo, M. Gomez-Heras \& C. Vazquez- 
Calvo (Eds.), Heritage Weathering and Conservation. Balkema, Rotterdam. pp. 513-519.

Gomez-Heras, M., Smith, B.J., Fort, R., 2008a. Influence of surface heterogeneities of building granite on its thermal microenvironment and its potential for the generation of thermal weathering. Environ. Geol. 56: 547-560.

Gomez-Heras, M., Smith, B.J., Viles, H.A., 2008b. Laboratory modelling of gypsum crust growth on limestone related to soot pollution and gaseous sulphur: implications of "cleaner" environments for stone decay. In: Lukaszewicz JW, Niemcewicz P. (Eds.), 11th International Congress on Deterioration and Conservation of Stone (2 volumes). Wydawnictwo Naukowe Universytetu Mikolaja Kopernika, Torun. pp. 275-282.

Gomez-Heras, M., McCabe, S., Smith, B.J., Fort, R., 2009. Impacts of Fire on StoneBuilt Heritage: an Overview. Journal of Architectural Conservation 15 (2), pp. 47-58.

Gomez-Heras, M., Smith, B.J., Viles, H.A., 2010. Oxford stone revisited: Causes and consequences of diversity in building limestone used in the historic centre of Oxford, England. In: Přikryl, R. and Török, A. (Eds.) Geological Society Special Publication 333 Natural Stone Resources for Historical Monuments. Geol. Soc. Publishing House, Bath: pp.101-110.

Goodchild, J.G., 1890. Notes on some observed rates of weathering of limestones. Geological Magazine 27, 463-466.

Goudie, A., 2000. The Human Impact on the Natural Environment (5th ed.) The MIT Press, Cambridge, MA

Hajpal, M., Török, A., 2004. Mineralogical and colour changes of quartz sandstones by heat, Environmental Geology 46, $311-322$. 
Hall, K., André, M.F., 2003. Rock thermal data at the grain scale: applicability to granular disintegration in cold environments. Earth Surf Process Land. 28, 823836

Hall, K., Thorn, C. E., Matsuoka, N., Prick, A., 2002. Weathering in cold regions: some thoughts and perspectives, Progress in Physical Geography 26, $577-603$.

Halsey, D.P., Mitchell, D.J., Dews, S.J., 1998. Influence of climatically induced cycles in physical weathering. Q J Eng Geol 31, 359-367

Howe, J.A., 1910. The Geology of Building Stones. Edward Arnold, London. 455 pp.

Jenkins, K.A., Smith, B.J., 1990. Daytime rock surface temperature variability and its implications for mechanical rock weathering: Tenerife, Canary Islands. Catena $17(4-5), 449-459$

Jones, D. K. C., 1999. On the uplift and denudation of the Weald, in B. J. Smith, W. B. Whalley, P. A. Warke (Eds.), Uplift, Erosion and Stability: Perspectives on Long-term Landscape Development, Geological Society, London, Special Publications 162, $25-43$.

Kennett, D.J., Beach, T.P., 2013. Archaeological and environmental lessons for the Anthropocene from the Classic Maya collapse. Anthropocene 4: 88-100.

Klein, M., 1984. Weathering rates of limestone tombstones measured in Haifa, Israel. Zeitschrift fur Geomorphologie, N.F. 28,105-111.

Kompaníková, Z., Gomez-Heras, M., Michňová, J., Durmeková, T., Vlčko, J., 2014. Sandstone alterations triggered by fire-related temperatures. Environmental Earth Sciences 72(7), 2569-2581.

La Russa, M.F, Belfiore, C.M., Comite, V., Barca, D., Bonazza, A., Ruffolo, S.A., Crisci, G.M., Pezzino A., 2013. Geochemical study of black crusts as a diagnostic tool in cultural heritage. Applied Physics A 113, 1151-1162 
Lyell, C., 1830. Principles of Geology. John Murray, London.

Martinez-Martinez, J., Benavente, D., Gomez-Heras, M., Marco-Castano, L., Garciadel-Cura, M.A., 2013. Non-linear decay of building stones during freeze-thaw weathering processes. Construction and Building Materials 38, 443-454.

Matthias, G.F., 1967. Weathering rates of Portland Arkose tombstones. Journal of Geological Education 15, 140-144

Maxwell, I., (Ed.) 2008. COST Action C17 Built Heritage: Fire Loss to Historic Buildings. Action C17 Publications. Historic Scotland, Edinburgh.

McAllister, D., 2014. Environmental Controls on Sandstone Decay: the Impact of Climate and Changing Dynamics, PhD thesis, Queen's University Belfast, UK.

McAllister, D., McCabe, S., Srinivasan, S., Smith, B. J., Warke, P. A., 2011. Moisture dynamics in building sandstone: monitoring strategies and implications for transport and accumulation of salts, in: Salt Weathering on Buildings and Stone Sculptures 2011, Cyprus, 39 - 46.

McAllister, D., McCabe, S., Smith, B. J., Srinivasan, S., Warke, P. A., 2013. Low temperature conditions in building sandstone: the role of extreme events in temperate environments. European Journal of Environmental and Civil Engineering 17:2, 99-112

McCabe, S., 2007. The impact of complex stress histories on the decay of historic sandstone, Ph.D. thesis, Queen's University Belfast, UK.

McCabe, S., Smith, B.J., Warke, P.A., 2006. Calcium loading of building sandstones by lime rendering: implications for decay, in R. Fort, M. Alvarez de Buergo, M. Gomez-Heras, C. Vazquez-Calvo (Eds.), Heritage, Weathering and Conservation, Taylor \& Francis Group, London, 177 - 182. 
McCabe S., Smith, B.J, Warke, P.A., 2007a. Preliminary observations on the impact of complex stress histories on sandstone response to salt weathering: laboratory simulations of processes combinations, Environmental Geology 52, 251 - 258.

McCabe S., Smith, B.J, Warke, P.A., 2007b. An holistic approach to the assessment of stone decay: Bonamargy Friary, Northern Ireland, in R. Přikryl, B. J. Smith (Eds.), Building Stone Decay: From Diagnosis to Conservation, Geological Society, London, Special Publications 271 (2007) 77 - 86.

McCabe, S., Smith, B. J., 2009. Understanding the long-term survival of sandstone in medieval ecclesiastical structures: Northern Ireland and western Scotland in M. Bostenaru Dan, R. Přikryl, A. Török (Eds.), Materials, Technologies and Practice in Historic Heritage Structures. Springer, Heidelburg, 107 - 136.

McCabe, S., Smith, B. J., Warke, P. A. 2010a. A legacy of mistreatment: conceptualising the decay of medieval sandstones in NE Ireland, in: Přikryl, R., Török, A. (Eds.), Natural Stone Resources for Historical Monuments, Geological Society, London, Special Publications 333, pp. 87 - 100.

McCabe, S., Smith, B.J, Warke, P.A., 2010b. Exploitation of inherited weakness in fire-damaged building sandstone: the 'fatiguing' of 'shocked' stone. Engineering Geology 115, 217 - 225.

McCabe, S., Smith, B. J., Adamson, C. S., Mullan, D., McAllister, D. 2011. The 'greening' of natural stone buildings: quartz sandstone performance as a secondary indicator of climate change in the British Isles? Atmospheric and Climate Sciences 1, 165 - 171 .

McCabe, S., Brimblecombe, P., Smith, B.J., McAllister, D., Srinivasan, S., Basheer, P.A.M., 2013a. The use and meanings of 'time of wetness' in understanding 
building stone decay Quarterly Journal of Hydrogeology and Engineering Geology 46, 469-476.

McCabe, S., Smith, B.J., McAlister, J.J., Gomez-Heras, M., McAllister, D., Warke, P.A., Curran, J.M., Basheer, P.A.M., 2013b. Changing climate, changing process: implications for salt transportation and weathering within building sandstones in the UK. Environmental Earth Sciences 69 (4): 1225-1235.

McCabe, S., McAllister, D., Warke, P.A., Gomez-Heras, M., 2015. Building sandstone surface modification by biofilm and iron precipitation: emerging block-scale heterogeneity and system response. Earth Surface Processes and Landforms 40, 112-122.

Meierding, T.C., 1993. Marble Tombstone Weathering and Air Pollution in North America. Annals of the Association of American Geographers 83 (4), 568-588.

Mingarro, F., 1996. Disgregación Mecánica de Materiales. In: F. Mingarro Martin (Ed.), Degradación y conservación del Patrimonio Arquitectónico. Editorial Complutense, Madrid, pp. 321-332.

Mol, L., 2014 Investigations into the relationship between changes in internal moisture regimes and rock surface deterioration in cavernous sandstone features. Earth Surf. Process. Landforms 39, 914-927.

Mol, L., Viles, H., 2012. Conservation of history in a changing environment: a geomorphological approach. In: Mol, Lisa and Sternberg, Troy eds. Changing Deserts: Integrating People and their Environment, Cambridge: White Horse Press, pp. 215-236

Muir, R., 2001 Landscape Detective: Discovering a Countryside, Windgather Press, Cheshire. 
Novakov, T., Chang, S.G., Harker, A.B., 1974. Sulfates as pollution particulates: catalytic formation on carbon (soot) particles. Science 186, 259-261.

Ozga, I., Ghedini, N., Giosuè, V., Sabbioni, C., Tittarelli, F., Bonazza, A., 2014. Assessment of air pollutant sources in the deposit on monuments by multivariate analysis. Science of the Total Environment, 490: 776-784.

Oldfield, F., Barnosky, A., Dearing, J., Fischer-Kowalski, M., McNeill, J., Steffen, W., Zalaseiwicz, J., 2014. The Anthropocene Review: Its significance, implications and the rationale for a new transdisciplinary journal. The Anthropocene Review 1:3-7.

Perez-Ema, N., Alvarez de Buergo, M., Bustamante, R., Gomez-Heras, M., Changes in Petrophysical Properties of the Stone Surface due to Past Conservation Treatments in Archaeological Sites of Merida (Spain). In Lollino, G., Giordan, D., Marunteanu, C., Christaras, B., Yoshinori, I., Margottini, C. (Eds.), Engineering Geology for Society and Territory 8, 521-524.

Perry, J., Falzon, C., 2014. Climate change adaptation for natural World Heritage sites: a practical guide. UNESCO, Paris.

Poblador Muga, M.P., 2001. Legislación internacional sobre patrimonio y restauración: Convenios y Cartas Internacionales. In: J. Gisbert Aguilar (Editor), I jornadas de Caracterización y Restauración de Materiales Pétreos en Arquitectura, Escultura y Restauración. Universidad de Zaragoza, Zaragoza, pp. 3-58.

Pope, G.A., Meierding, T.C., Paradise, T.R., 2002. Geomorphology's role in the study of weathering of cultural stone. Geomorphology 47 (2), 211-225

Price, C.A., 1996. Stone conservation: an overview of current research. Getty Conservation Institute, Santa Monica, CA, xiii, 73 pp. 
Rick, T.C., Kirch, P.V., Erlandson, J.M., Fitzpatrick, S.M., 2013. Archeology, deep history, and the human transformation of island ecosystems. Anthropocene 4: $33-45$.

Rodrigues da Costa, J., Rodrigues, D., 2011. The effect of water on the durability of granitic materials consolidated with Ethyl Silicates. In: Adhesives and Consolidants in Conservation: Research and Application. CCI SymposiumOttawa, Canada.

Rodriguez-Navarro C. \& Sebastian E. 1996. Role of particulate matter from vehicle exhaust on porous stones (limestone) sulfation. The Science of the Total Environment 187, 79-91.

Rodriguez-Navarro, C., Cazalla, O., Elert, K., Sebastian, E., 2002. Liesegang pattern development in carbonating traditional lime mortars. Proceedings of the Royal Society of London A 458, 2261-2273.

Ruddiman, W.F, Ellis, E.C., Kaplan, J.O., Fuller, D.Q., 2015. Defining the epoch we live in. Science 348 (6230), 38-39.

Ruffolo, S.A., Comite, V., La Russa, M.F, Belfiore, C.M., Barca, D., Bonazza, A., Crisci, G.M., Pezzino A., Sabbioni, C., 2015. An analysis of the black crusts from the Seville Cathedral: A challenge to deepen the understanding of the relationships among microstructure, microchemical features and pollution sources. Science of the Total Environment 502, 157-166.

Sabbioni C, Cassar M, Brimblecombe P, Tidblad J, Kozlowski R, Drdacky M, SaizJimenez C, Grontoft T, Wainwright I, Arino X, 2006. Global climate change impact on built heritage and cultural landscapes. In: Heritage, Weathering and Conservation, Fort R, Alvarez De Buergo M, Gomez-Heras M, Vazquez-Calvo C (Eds.). Taylor and Francis, London. pp. 395-401. 
Schaffer, R.J., 1932. The weathering of natural building stones. Building Research Establishment, Watford, x, 149 pp.

Siegesmund S, Török A, Hupers A, Muller C, Klemm W (2007) Mineralogical, geochemical and microfabric evidences of gypsum crusts: a case study from Budapest. Environmental Geology 52, 385-397.

Simmons, I. G., 1974. The Ecology of Natural Resources. Edward Arnold, London, $424 \mathrm{pp}$.

Smith, B.D., Zeder, M.A., 2013. The onset of the Anthropocene. Anthropocene 4: 813.

Smith, B.J., Prrikryl, R., 2007. Diagnosing decay: the value of medical analogy in understanding the weathering of building stones, in R. Prrikryl, B. J. Smith (Eds.), Building Stone Decay: From Diagnosis to Conservation, Geological Society, London, Special Publications 271, $1-8$.

Smith, B.J., Whalley, W.B., Warke, P.A., Ruffell, A., 1999. Introduction and background: interpretations of landscape change, in B. J. Smith, W. B. Whalley, P. A. Warke (Eds.), Uplift, Erosion and Stability: Perspectives on Long-term Landscape Development, Geological Society, London, Special Publications 162, vii - xi.

Smith, B. J., Turkington, A. V., Curran, J. M., 2001. Calcium loading of quartz sandstones during construction: implications for future decay. Earth Surface Processes and Landforms 26: $877-883$.

Smith, B. J., Turkington, A. V., Warke, P. A., Basheer, P. A. M., McAlister, J. J., Meneely, J., Curran, J. M., 2002. Modelling the rapid retreat of building sandstones: a case study from a polluted maritime environment, in S. Seigesmund, T. Weiss, A. Vollbrecht (Eds.), Natural Stone, Weathering 
Phenomenon, Conservation Strategies and Case Studies, Geological Society, London, Special Publications, $347-362$.

Smith B.J., Gomez-Heras, M. McCabe, S., 2008. Understanding the decay of stonebuilt cultural heritage. Progress in Physical Geography 32(4), 439-461.

Smith, B.J., McCabe, S., McAllister, D., Adamson, C., Viles, H.A., Curran, J.M., 2011a. A commentary on climate change, stone decay dynamics and the 'greening' of natural stone buildings: new perspectives on 'deep wetting'. Environmental Earth Sciences 63, 1691-1700.

Smith, B. J., Srinivasan, S., McCabe, S., McAllister, D., Cutler, N., Basheer, P. A. M., Viles, H. A., 2011b. Climate change and the investigation of complex moisture regimes in heritage stone: preliminary observations on possible strategies, Materials Evaluation 69(1), 48 - 58

Swindles, G. T. 2006. Reconstruction of Holocene climate change from peatlands in the north of Ireland. Unpublished PhD thesis, Queen's University, Belfast.

Thornes, J.B., Brunsden, D., 1977. Geomorphology and Time, Methuen \& Co Ltd, London.

Török, A., Licha, T., Simon, K., Siegesmund, S., 2011. Urban and rural limestone weathering; the contribution of dust to black crust formation Environmental Earth Sciences 63, 675-693.

Varas, M.J., Alvarez de Buergo, M., Fort, R., 2005. Natural cement as the precursor of Portland cement: Methodology for its identification. Cement and Concrete Research 35 (11), 2055-2065.

Varas, M.J., Alvarez de Buergo, M., Fort, R., 2007. The influence of past protective treatments on the deterioration of historic stone façades: a case study. Studies in Conservation 52, 110-125. 
Varas-Muriel, M.J., Pérez-Monserrat, E.M., Vázquez-Calvo, C., Fort, R., 2015. Effect of conservation treatments on heritage stone. Characterisation of decay processes in a case study. Construction and Building Materials 95, 611-622.

Vazquez, P., Shushakova, V., Gomez-Heras, M., 2015. Influence of mineralogy on granite decay induced by temperature increase: Experimental observations and stress simulation. Engineering Geology 189, 58-67.

Vazquez-Calvo, Alvarez de Buergo, M., Fort, R., 2007. Overview of recent knowledge of patinas on stone monuments: the Spanish experience. in R. Přikryl, B. J. Smith (Eds.), Building Stone Decay: From Diagnosis to Conservation, Geological Society, London, Special Publications 271, 295-307.

Viles, H.A., 2002. Implications of future climate change for stone deterioration. In: Seigesmund S, Weiss T, Volbrecht A (eds.) Natural Stone, Weathering Phenomenon, Conservation Strategies and Case Studies. Geological Society, London, Special Publications, 205, pp 407-418.

Warke, P.A., 2007. Complex weathering in drylands: implications for rock breakdown and sediment release, Geomorphology 85, $30-48$.

Waters, C.N., Zalasiewic, J.A., Williams, M., Ellis, M.A., Snelling, A.M., 2014. A stratigraphical basis for the Anthropocene? In: Waters, C.N., Zalasiewic, J.A., Williams, M., Ellis, M.A., Snelling, A.M., 2014. A stratigraphical basis for the Anthropocene. Geological Society, London, Special Publications, 395, 1-21.

Wilkins, S., Compton, R.G., Taylor, M.P. and Viles, H.A., 2001. Channel flow cell studies of the inhibiting action of gypsum on the dissolution kinetics of calcite: a laboratory approach with implications for field monitoring. Journal of Colloid and Interface Science 236(2), 354-361. 
Wilkins, S., Compton, R.G., Viles. H.A. and Taylor M.P. 2002. A new technique to evaluate and quantify the role of surface treatments in reducing the dissolution of calcareous building materials. Studies in Conservation 47, 88-94.

Winkler, E.M., 1973. Stone: Properties, Durability in Man's Environment. Springer Verlag, Berlin, 230 pp.

Woodcock, D. G., 1997. Reading Buildings Instead of Books: Historic Structure Reports as Learning Tools, APT Bulletin 28(1).

World Heritage Committee, 2005. Decisions of the $29^{\text {th }}$ session of the World Heritage Committee

WHC-05/29.COM/22 http://whc.unesco.org/archive/2005/whc29com-22e.pdf

Young, M. E., 2006. Granite soiling and decay in Aberdeen, UK: pollutants, stone characteristics and mortars. In: Fort, R., Alvarez de Buergo, M., Gomez-Heras, M. \& Vazquez-Calvo, C. (eds.), Heritage, Weathering and Conservation. Taylor \& Francis Group, London: 425 - 433. 